\title{
Allylic Ionization vs. Oxidative Addition into Vinyl C-X Bonds by Pd With Polyfunctional Olefin Templates.
}

Michael G. Organ, * Eamon Comer and Stephen J. Hynes

The Department of Chemistry York University, 4700 Keele Street,

Toronto, Ontario, Canada, M3J 1P3

\section{SUPPORTING INFORMATION}

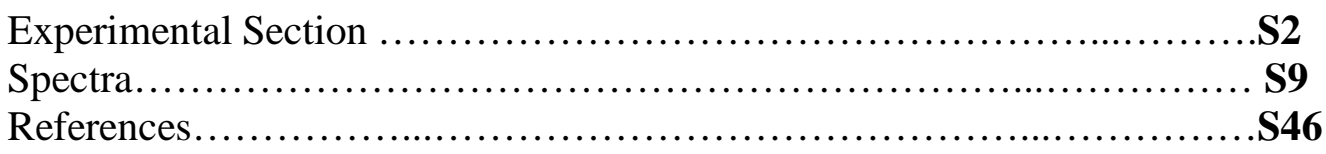

\begin{tabular}{|c|c|c|}
\hline Compound & Spectra & Page \\
\hline 6 & ${ }^{1} \mathrm{H}$ NMR & S9 \\
\hline 6 & ${ }^{13} \mathrm{C}$ NMR & S10 \\
\hline 7 & ${ }^{1} \mathrm{H}$ NMR & S11 \\
\hline 7 & ${ }^{13} \mathrm{C}$ NMR & S12 \\
\hline 8 & ${ }^{1} \mathrm{H}$ NMR & S13 \\
\hline 8 & ${ }^{13} \mathrm{C}$ NMR & S14 \\
\hline 9 & ${ }^{1} \mathrm{H}$ NMR & S15 \\
\hline 9 & ${ }^{13} \mathrm{C}$ NMR & S16 \\
\hline 10 & ${ }^{1} \mathrm{H}$ NMR & S17 \\
\hline 10 & ${ }^{13} \mathrm{C}$ NMR & S18 \\
\hline 11 & ${ }^{1} \mathrm{H}$ NMR & S19 \\
\hline 11 & ${ }^{13} \mathrm{C}$ NMR & S20 \\
\hline $12 \& 13$ & ${ }^{1} \mathrm{H}$ NMR & S21 \\
\hline $12 \& 13$ & ${ }^{13} \mathrm{C}$ NMR & S22 \\
\hline $15 \& 16$ & ${ }^{1} \mathrm{H}$ NMR & $\mathbf{S 2 3}$ \\
\hline $15 \& 16$ & ${ }^{13} \mathrm{C}$ NMR & S24 \\
\hline 18 & ${ }^{1} \mathrm{H}$ NMR & S25 \\
\hline $18 \& 19$ & ${ }^{1} \mathrm{H}$ NMR & S26 \\
\hline 20 & ${ }^{1} \mathrm{H}$ NMR & S27 \\
\hline 21 & ${ }^{1} \mathrm{H}$ NMR & S28 \\
\hline 21 & ${ }^{13} \mathrm{C}$ NMR & S29 \\
\hline $22 \& 23$ & ${ }^{1} \mathrm{H}$ NMR & S30 \\
\hline $22 \& 23$ & ${ }^{13} \mathrm{C}$ NMR & S31 \\
\hline $24 \& 25$ & ${ }^{1} \mathrm{H}$ NMR & S32 \\
\hline $24 \& 25$ & ${ }^{13} \mathrm{C}$ NMR & S33 \\
\hline 34b & ${ }^{1} \mathrm{H}$ NMR & S34 \\
\hline
\end{tabular}


${ }^{1} \mathrm{H}$ NMR $\quad$ S36

${ }^{13} \mathrm{C}$ NMR $\quad$ S37

${ }^{1} \mathrm{H}$ NMR $\quad$ S38

${ }^{13} \mathrm{C}$ NMR $\quad$ S39

${ }^{1} \mathrm{H}$ NMR $\quad$ S40

${ }^{13} \mathrm{C}$ NMR $\quad$ S41

${ }^{1} \mathrm{H}$ NMR $\quad \mathbf{S 4 2}$

${ }^{13} \mathrm{C}$ NMR $\quad \mathbf{S 4 3}$

${ }^{1} \mathrm{H}$ NMR $\quad \mathbf{S 4 4}$

${ }^{13} \mathrm{C}$ NMR $\quad$ S45

\section{Experimental Section}

General procedure. All reactions were carried out under a positive atmosphere of dry nitrogen. Tetrahydrofuran (THF) was distilled from sodium benzophenone immediately prior to use. Proton NMR spectra were recorded on a Brucker Advance spectrometer at $400 \mathrm{MHz}$. Carbon NMR were recorded on a Brucker Advance spectrometer at $100 \mathrm{MHz}$

\section{Procedures for the Preparation of Deuterated Starting Materials.}

2-Bromo-1,1-dideuterioprop-2-en-1-yl) acetate (11). To a solution of 2-bromo-1,1dideuterioprop-2-en-1-ol ${ }^{1}(558 \mathrm{mg}, 4.01 \mathrm{mmol})$ in $\mathrm{CH}_{2} \mathrm{Cl}_{2}(20 \mathrm{~mL})$ was added pyridine $(0.36 \mathrm{~mL}, 4.42 \mathrm{mmol})$ followed by $\mathrm{N}, \mathrm{N}-$ dimethylaminopyridine $(10 \mathrm{mg}, 0.08 \mathrm{mmol})$. The solution was cooled to $0{ }^{\circ} \mathrm{C}$ and a solution of acetyl chloride $(0.31 \mathrm{~mL}, 4.42 \mathrm{mmol})$ in $\mathrm{CH}_{2} \mathrm{Cl}_{2}(4 \mathrm{~mL})$ was added dropwise. After stirring at $0{ }^{\circ} \mathrm{C}$ for $1 \mathrm{~h}$ and then at $\mathrm{rt}$ for 30 min, the reaction mixture was diluted with $\mathrm{CH}_{2} \mathrm{Cl}_{2}(10 \mathrm{~mL})$ and $10 \mathrm{~mL}$ of aqueous $1 \mathrm{M}$ $\mathrm{HCl}$ was added. The organic layer was separated and the aqueous layer extracted with $\mathrm{CH}_{2} \mathrm{Cl}_{2}(2 \times 10 \mathrm{~mL})$. The combined organic layers were dried over anhydrous $\mathrm{MgSO}_{4}$, filtered, and the solvent removed in vacuo. Purification by flash chromatography (80:20 pentane/ether) afforded $618 \mathrm{mg}$ of $\mathbf{1 1}$ as a clear liquid (85\% yield). ${ }^{1} \mathrm{H} \mathrm{NMR}\left(\mathrm{CDCl}_{3}, 400\right.$ $\mathrm{MHz}) \delta 5.91(\mathrm{~s}, 1 \mathrm{H}), 5.66(\mathrm{~s}, 1 \mathrm{H}), 2.14(\mathrm{~s}, 3 \mathrm{H}) ;{ }^{13} \mathrm{C} \mathrm{NMR}\left(\mathrm{CDCl}_{3}, 100 \mathrm{MHz}\right) \delta 170.0$, $126.3,119.1,65.8,20.7$.

These data are consistent with the literature data for the analogous non-deuterated analogue $^{2}$

(2Z)-3-Bromo-1,1-dideuterioprop-2-en-1-yl acetate (37). To a solution of (2Z)-3bromo-1,1-dideuteriopropen-1-ol ${ }^{3}$ (785 mg, $\left.5.45 \mathrm{mmol}\right)$ in $\mathrm{CH}_{2} \mathrm{Cl}_{2}(25 \mathrm{~mL})$ was added, pyridine $(0.48 \mathrm{~mL}, 6.0 \mathrm{mmol})$, followed by $\mathrm{N}, \mathrm{N}$-dimethylaminopyridine $(13 \mathrm{mg}, 0.109$ mmol). After cooling to $0{ }^{\circ} \mathrm{C}$, a solution of acetyl chloride $(0.43 \mathrm{~mL}, 6.0 \mathrm{mmol})$ in $\mathrm{CH}_{2} \mathrm{Cl}_{2}(5 \mathrm{~mL})$ was added dropwise. The resultant solution was stirred at $0{ }^{\circ} \mathrm{C}$ for $1 \mathrm{~h}$ and then at $\mathrm{rt}$ for $1 \mathrm{~h}$. The reaction mixture was diluted with $\mathrm{CH}_{2} \mathrm{Cl}_{2}(8 \mathrm{~mL})$ and $10 \mathrm{~mL}$ of aqueous $1 \mathrm{M} \mathrm{HCl}$ was added. The organic layer was separated and the aqueous layer extracted with $\mathrm{CH}_{2} \mathrm{Cl}_{2}(2 \times 8 \mathrm{~mL})$. The combined organic layers were dried over 
anhydrous $\mathrm{MgSO}_{4}$, filtered and the solvent removed in vacuo. Purification by flash chromatography (80:20 pentane/ether) afforded $880 \mathrm{mg}$ of $\mathbf{3 7}$ as an oil (89\% yield). ${ }^{1} \mathrm{H}$ NMR $\left(\mathrm{CDCl}_{3}, 400 \mathrm{MHz}\right) \delta 6.37(\mathrm{~d}, J=6.8 \mathrm{~Hz}, 1 \mathrm{H}), 6.27(\mathrm{~d}, J=6.8 \mathrm{~Hz}, 1 \mathrm{H}), 2.06(\mathrm{~s}, 3 \mathrm{H})$; ${ }^{13} \mathrm{C} \mathrm{NMR}\left(\mathrm{CDCl}_{3}, 100 \mathrm{MHz}\right) \delta 170.6,129.3,111.1,61.7(\mathrm{~m}), 20.7$.

(4Z)-5-Bromo-3-deuteriopenta-2,4-dien-1-yl acetate (39). Mixture of $2 E$ and $2 Z$ isomers. A mixture of (2Z)-3-bromo-1,1-dideuteriopropen-1-ol ${ }^{3}$ (303 mg, 2.18 mmol), ethyl (triphenylphosphoranylidene)acetate $(912 \mathrm{mg}, 2.62 \mathrm{mmol})$ and manganese dioxide $(1.90 \mathrm{~g}, 21.80 \mathrm{mmol})$ in $\mathrm{CH}_{2} \mathrm{Cl}_{2}(60 \mathrm{~mL})$ was stirred at $\mathrm{rt}$ for $12 \mathrm{~h}$. The manganese dioxide was removed by passing the reaction mixture through a pad of Celite and washing with methylene chloride. The solvent was then removed in vacuo. Purification by flash chromatography (90:10 pentane/ether) afforded $271 \mathrm{mg}$ of ethyl-5-bromo-3deuteriopenta-4Z-dienoate as a mixture of $2 E$ and $2 Z$ isomers (60\% yield). A solution of this material $(210 \mathrm{mg}, 1.02 \mathrm{mmol})$ in ether $(5 \mathrm{~mL})$ was added slowly to a stirred suspension of LAH (42 mg, $1.1 \mathrm{mmol})$ in ether $(15 \mathrm{~mL})$ at $0{ }^{\circ} \mathrm{C}$. The reaction was stirred for $3 \mathrm{~h}$ after which it was quenched by the successive addition of $\mathrm{H}_{2} \mathrm{O}(0.1 \mathrm{~mL}), 15 \%$ $\mathrm{NaOH}(0.1 \mathrm{~mL})$ and $\mathrm{H}_{2} \mathrm{O}(0.1 \mathrm{~mL})$. The liquid was decanted and the remaining solid was washed with ether $(3 \mathrm{x} 4 \mathrm{~mL})$. The combined organic components were dried over anhydrous $\mathrm{MgSO}_{4}$, filtered and the solvent removed in vacuo. Purification by flash chromatography (70:30 pentane/ether) afforded $126 \mathrm{mg}$ of (4Z)-5-bromo-3-deuterio-2,4dien-1-ol as a mixture of $2 E$ and $2 Z$ isomers. This material was subjected to the action of pyridine $(0.068 \mathrm{~mL}, 0.845 \mathrm{mmol}), \mathrm{N}, \mathrm{N}$-dimethylaminopyridine $(2 \mathrm{mg}, 0.015 \mathrm{mmol})$ and acetyl chloride $(0.06 \mathrm{~mL}, 0.845 \mathrm{mmol})$ as above to afford $97 \mathrm{mg}$ of an inseparable mixture of $2 E$ and $2 Z$ isomers of $\mathbf{3 9}$ as an oil (46\% yield for 2 steps) (ratio, EZ:ZZ, 77:23). Major isomer. ${ }^{1} \mathrm{H} \mathrm{NMR}\left(400 \mathrm{MHz}, \mathrm{CDCl}_{3}\right) \delta 6.63(\mathrm{~d}, J=6.9 \mathrm{~Hz}, 1 \mathrm{H}), 6.22(\mathrm{~d}, J=6.9$ $\mathrm{Hz}, 1 \mathrm{H}), 5.96$ (br s, 1H), 4.63 (d, $J=5.6 \mathrm{~Hz}, 2 \mathrm{H}), 2.08$ (s, 3H).

Attempted allylic substiution of 2-bromocyclohex-2-en-1-yl acetate (2a). Preparation of 2-bromocyclohex-2-en-1-ol (6). To a solution of dimethyl methylmalonate (72 $\mathrm{mg}$, $0.49 \mathrm{mmol})$ in THF ( $3 \mathrm{~mL})$ was added $\mathrm{NaH}(20 \mathrm{mg}, 0.49 \mathrm{mmol}$ of a $60 \%$ dispersion in mineral oil) in small batches. The resulting solution was stirred for $10 \mathrm{~min}$. at $\mathrm{rt}$ and then $\left(\mathrm{PPh}_{3}\right)_{4} \mathrm{Pd}(26 \mathrm{mg}, 0.023 \mathrm{mmol})$ was added followed immediately by a solution of $\mathbf{2} \mathbf{a}^{4}$ (98 $\mathrm{mg}, 0.45 \mathrm{mmol})$ in THF (3 mL). The resulting solution was stirred at $\mathrm{rt}$ for $17 \mathrm{~h}$ and then at $55{ }^{\circ} \mathrm{C}$ for $4 \mathrm{~h}$ after which it was quenched with $\mathrm{H}_{2} \mathrm{O}$ and diluted with pentane. The organic layer was separated, dried over anhydrous $\mathrm{MgSO}_{4}$, filtered and the solvent removed in vacuo to give an oil. The residue was then purified by flash chromatography (80:20 pentane/ether) to afford $35 \mathrm{mg}$ of $\mathbf{6}$ as an oil (44\% yield, $73 \%$ yield based on recovered 2a) along with $38 \mathrm{mg}$ of $\mathbf{2 a}\left(39 \%\right.$ recovery). ${ }^{1} \mathrm{H} \mathrm{NMR}\left(400 \mathrm{MHz}, \mathrm{CDCl}_{3}\right) \delta$ $6.21(\mathrm{t}, J=4.0 \mathrm{~Hz}, 1 \mathrm{H}), 4.22$ (br s, $1 \mathrm{H}), 1.57-2.18(\mathrm{~m}, 6 \mathrm{H}) ;{ }^{13} \mathrm{C} \mathrm{NMR}\left(\mathrm{CDCl}_{3}, 100 \mathrm{MHz}\right)$ $\delta 132.6,125.9,69.9,32.0,27.8,17.7$.

These data agree with the literature data ${ }^{5}$

Dimethyl (2-bromoprop-2-en-1-yl)(methyl)malonate (8). To a solution of dimethyl methylmalonate $(82 \mathrm{mg}, 0.56 \mathrm{mmol})$ in THF $(2 \mathrm{~mL})$ was added $\mathrm{NaH}(22 \mathrm{mg}, 0.56 \mathrm{mmol}$ of a $60 \%$ dispersion in mineral oil) in small batches. The resulting solution was stirred for 
$10 \mathrm{~min}$. at $\mathrm{rt}$ and then $\left(\mathrm{PPh}_{3}\right)_{4} \mathrm{Pd}(32 \mathrm{mg}, 0.028 \mathrm{mmol})$ was added followed immediately by a solution of $7(100 \mathrm{mg}, 0.56 \mathrm{mmol})$ in THF $(2 \mathrm{~mL})$. The resulting solution was stirred at $\mathrm{rt}$ for $16 \mathrm{~h}$ after which it was diluted with pentane and the precipitated solids were removed by filtration. The solvent was removed in vacuo and the residue was purified by flash chromatography (90:10 pentane/ether) to afford $96 \mathrm{mg}$ of $\mathbf{8}$ as an oil (64\% yield). ${ }^{1} \mathrm{H}$ NMR $\left(400 \mathrm{MHz}, \mathrm{CDCl}_{3}\right) \delta 5.65(\mathrm{~s}, 1 \mathrm{H}), 5.58(\mathrm{~s}, 1 \mathrm{H}), 3.74(\mathrm{~s}, 6 \mathrm{H}), 3.15(\mathrm{~s}, 2 \mathrm{H}), 1.49$ $(\mathrm{s}, 3 \mathrm{H}) ;{ }^{13} \mathrm{C} \mathrm{NMR}\left(\mathrm{CDCl}_{3}, 100 \mathrm{MHz}\right) \delta 171.7,127.3,121.8,53.1,52.8,46.1,19.4$.

These data are consistent with the literature data ${ }^{6}$

2-(4-Methoxyphenyl)prop-2-en-1-yl acetate (9).

A suspension of 4-methoxyphenyl boronic acid $(127.5 \mathrm{mg}, 0.84 \mathrm{mmol})$ and cesium fluoride $(1.02 \mathrm{~g}, 6.73 \mathrm{mmol})$ in THF $(2 \mathrm{~mL})$ was stirred for $10 \mathrm{~min}$ at $\mathrm{rt}$. A THF $(2 \mathrm{~mL})$ solution containing $\left(\mathrm{PPh}_{3}\right)_{4} \mathrm{Pd}(97 \mathrm{mg}, 0.084 \mathrm{mmol})$ and $7(300 \mathrm{mg}, 1.68 \mathrm{mmol})$ was then added and the reaction stirred at $60{ }^{\circ} \mathrm{C}$ for $16 \mathrm{~h}$. The reaction mixture was diluted with pentane, the solids were removed by filtration and the solvent removed in vacuo. The residue was then purified by flash chromatography (95:5 pentane/ether) to afford $\mathbf{9}$ as a colourless oil $(152 \mathrm{mg}, 88 \%) .{ }^{1} \mathrm{H}$ NMR $\left(400 \mathrm{MHz}, \mathrm{CDCl}_{3}\right) \delta 7.38(\mathrm{~d}, J=8.8 \mathrm{~Hz}, 2 \mathrm{H})$, $6.98(\mathrm{~d}, J=8.8 \mathrm{~Hz}, 2 \mathrm{H}), 5.48(\mathrm{~s}, 1 \mathrm{H}), 5.28(\mathrm{~s}, 1 \mathrm{H}), 4.96(\mathrm{~s}, 2 \mathrm{H}), 3.83(\mathrm{~s}, 3 \mathrm{H}), 2.08(\mathrm{~s}, 3 \mathrm{H})$; ${ }^{13} \mathrm{C}$ NMR $\left(\mathrm{CDCl}_{3}, 100 \mathrm{MHz}\right) 170.8,159.6,141.8,130.5,127.1,113.7,113.9,65.9,55.3$, 21.0.

These data agree with the literature data ${ }^{7}$

Concurrent Pd-Catalyzed Suzuki and Allylic Substitution Reactions With 2bromoprop-2-en-1-yl acetate (7). Dimethyl[2-(4-methoxyphenyl)prop-2-en-1yl](methyl)malonate (10). To a solution of dimethyl methylmalonate $(82 \mathrm{mg}, 0.56$ $\mathrm{mmol})$ in THF $(3 \mathrm{~mL})$ was added slowly $\mathrm{NaH}(22 \mathrm{mg}, 0.56 \mathrm{mmol}$ of a $60 \%$ dispersion in mineral oil) and the resulting solution was stirred for $10 \mathrm{~min}$ at rt. 4-Methoxyphenyl boronic acid ( $85 \mathrm{mg}, 0.56 \mathrm{mmol})$, cesium fluoride $(340 \mathrm{mg}, 2.24 \mathrm{mmol})$ and a solution of $7(100 \mathrm{mg}, 0.56 \mathrm{mmol})$ in THF $(1 \mathrm{~mL})$ was then added. A solution of $\mathrm{Pd}\left(\mathrm{PPh}_{3}\right)_{4}(32 \mathrm{mg}$ $0.028 \mathrm{mmol})$ in THF $(2 \mathrm{~mL})$ was added via syringe. After $2 \mathrm{~h}$ the starting material was completely consumed and $\mathbf{8}$ was observed to be the reaction product by NMR spectroscopy. No cross-coupling products were apparent. The reaction temperature was increased to $60{ }^{\circ} \mathrm{C}$ and stirred for a further $13 \mathrm{~h}$. The reaction mixture was then diluted with pentane, filtered and the solvent removed in vacuo. Purification by flash chromatography (80:20 pentane/ether) afforded $65 \mathrm{mg}$ of $\mathbf{1 0}$ as a clear oil $(39 \%) .{ }^{1} \mathrm{H}$ NMR $\left(400 \mathrm{MHz}, \mathrm{CDCl}_{3}\right) \delta 7.25(\mathrm{~d}, J=8.6 \mathrm{~Hz}, 2 \mathrm{H}), 7.24(\mathrm{~d}, J=8.6 \mathrm{~Hz}, 2 \mathrm{H}), 5.20(\mathrm{~s}$, $1 \mathrm{H}), 5.03(\mathrm{~s}, 1 \mathrm{H}), 3.79(\mathrm{~s}, 3 \mathrm{H}), 3.50(\mathrm{~s}, 6 \mathrm{H}), 3.14(\mathrm{~s}, 2 \mathrm{H}), 1.31(\mathrm{~s}, 3 \mathrm{H}) ;{ }^{13} \mathrm{C} \mathrm{NMR}\left(\mathrm{CDCl}_{3}\right.$, $100 \mathrm{MHz}) \delta 172.2,159.1,143.8,134.0,128.0,117.0,113.5,55.3,53.5,52.3,40.7,20.0$. These data agree with the literature data ${ }^{6}$

Pd-catalyzed substitution reaction with 2-bromo-1,1-dideuterioprop-2-en-1-yl acetate (11). Inseparable mixture of 12 and 13 (Scheme 2, entry e). To a solution of dimethyl methylmalonate $(51 \mathrm{mg}, 0.35 \mathrm{mmol})$ in THF $(2 \mathrm{~mL})$ was added $\mathrm{NaH}(14 \mathrm{mg}$, $0.35 \mathrm{mmol}$ of a $60 \%$ dispersion in mineral oil) in small batches. The resulting solution was stirred for $10 \mathrm{~min}$. at $\mathrm{rt}$ and then $\left(\mathrm{PPh}_{3}\right)_{4} \mathrm{Pd}(402 \mathrm{mg}, 0.35 \mathrm{mmol})$ was added followed 
immediately by a solution of $\mathbf{1 1}(63 \mathrm{mg}, 0.35 \mathrm{mmol})$ in THF $(2 \mathrm{~mL})$. The reaction mixture was stirred at $\mathrm{rt}$ for $2 \mathrm{~h}$ after which it was diluted with pentane and the solids were removed by filtration. The solvent was removed in vacuo and the residue was then purified by flash chromatography (80:20 pentane/ether) to afford $37 \mathrm{mg}$ of an inseparable mixture of $\mathbf{1 2}$ and $\mathbf{1 3}$ as an oil (39\% yield, 51\% based on recovered 11) along with $14 \mathrm{mg}$ of 11 (22\% recovery). Inseparable mixture of 12 and 13. ${ }^{1} \mathrm{H}$ NMR $\left(\mathrm{CDCl}_{3}, 400 \mathrm{MHz}\right)$ $\delta 5.66(\mathrm{~s}, 1 \mathrm{H}), 5.59(\mathrm{~s}, 1 \mathrm{H}), 3.75(\mathrm{~s}, 12 \mathrm{H}), 3.16(\mathrm{~s}, 2 \mathrm{H}), 1.50(\mathrm{~s}, 6 \mathrm{H}) ;{ }^{13} \mathrm{C} \mathrm{NMR}\left(\mathrm{CDCl}_{3}\right.$, $100 \mathrm{MHz}) \delta 171.7,127.2,121.9,53.0,52.5,46.1,19.4$; HRMS calcd for $\mathrm{C}_{9} \mathrm{H}_{12} \mathrm{D}_{2} \mathrm{O}_{4} \mathrm{Br}$ $[\mathrm{M}]^{+}$267.0201, found 267.0160.

Reaction of dimer 14 with sodium acetate in the presence of silver acetate and triphenylphosphine. To a solution of dimer $\mathbf{1 4}^{8}(41 \mathrm{mg}, 0.067 \mathrm{mmol})$ in THF (5 $\mathrm{mL}$ ) was added silver acetate ( $22 \mathrm{mg}, 0.134 \mathrm{mmol}, 2$ equiv). The suspension was stirred for $10 \mathrm{~min}$ and filtered through a short plug of celite; the solid was washed with THF. The filtrate was collected in a flask containing triphenylphosphine $(88 \mathrm{mg}, 0.335 \mathrm{mmol}, 5$ equiv). The resultant yellow solution was stirred for 5 min and then sodium acetate was added $(11 \mathrm{mg}, 0.134 \mathrm{mmol})$ as a solid. The reaction was stirred at $\mathrm{rt}$ for $16 \mathrm{~h}$ and the solvent was then removed under reduced pressure. Purification by flash chromatography (80:20 pentane/ether) afforded $9 \mathrm{mg}$ of 2-bromoprop-2-en-1-yl acetate (7) as an oil $(38 \%) .{ }^{1} \mathrm{H}$ NMR $\left(\mathrm{CDCl}_{3}, 300 \mathrm{MHz}\right) \delta 5.90(\mathrm{~s}, 1 \mathrm{H}), 5.65(\mathrm{~s}, 1 \mathrm{H}), 4.70(\mathrm{~s}, 2 \mathrm{H}), 2.13(\mathrm{~s}, 3 \mathrm{H})$;

${ }^{13} \mathrm{C} \mathrm{NMR}\left(75 \mathrm{MHz}, \mathrm{CDCl}_{3}\right) \delta 169.8,126.3,119.0,67.5,20.7$.

These data are consistent with the literature data ${ }^{2}$

Concurrent Pd-Catalyzed Suzuki and Allylic Substitution Reactions with 2-bromo1,1-dideuterioprop-2-en-1-yl acetate (11). Inseparable mixture of 15 and 16. To a suspension of $\mathrm{NaH}(18 \mathrm{mg}, 0.46 \mathrm{mmol}, 60 \%$ dispersion in mineral oil) in THF ( $3 \mathrm{~mL})$ was added dimethyl methylmalonate $(67 \mathrm{mg}, 0.46 \mathrm{mmol})$ in THF $(2.5 \mathrm{~mL})$. The resulting solution was stirred for ten minutes at rt. 4-Methoxyphenyl boronic acid (70 mg, 0.46 $\mathrm{mmol}$ ), cesium fluoride (382 mg, $2.52 \mathrm{mmol})$ and a solution of $11(76 \mathrm{mg}, 0.42 \mathrm{mmol})$ in THF $(2 \mathrm{~mL})$ was then added. The suspension was heated to reflux upon which a solution of $\mathrm{Pd}\left(\mathrm{PPh}_{3}\right)_{4}(24 \mathrm{mg} 0.021 \mathrm{mmol})$ in THF $(1.5 \mathrm{~mL})$ was added. The reaction was strirred at reflux for a further $4 \mathrm{~h}$, quenched with $\mathrm{H}_{2} \mathrm{O}$ and diluted with pentane. The organic layer was separated, dried over anhydrous $\mathrm{MgSO}_{4}$, filtered and the solvent was removed in vacuo. Purification by flash chromatography (80:20 pentane/ether) afforded $37 \mathrm{mg}$ of an inseparable mixture of $\mathbf{1 5}$ and $\mathbf{1 6}$ as a clear oil (30\% yield). Inseparable mixture of $\mathbf{1 5}$ and 16. ${ }^{1} \mathrm{H} \mathrm{NMR}\left(\mathrm{CDCl}_{3}, 400 \mathrm{MHz}\right) \delta 7.25(\mathrm{~d}, J=8.8 \mathrm{~Hz}, 4 \mathrm{H}), 6.83(\mathrm{~d}, J=8.8 \mathrm{~Hz}, 4 \mathrm{H})$, $5.21(\mathrm{~s}, 1 \mathrm{H}), 5.03(\mathrm{~s}, 1 \mathrm{H}), 3.80(\mathrm{~s}, 6 \mathrm{H}), 3.51(\mathrm{~s}, 12 \mathrm{H}), 3.14(\mathrm{~s}, 2 \mathrm{H}), 1.31(\mathrm{~s}, 6 \mathrm{H}) ;{ }^{13} \mathrm{C}$

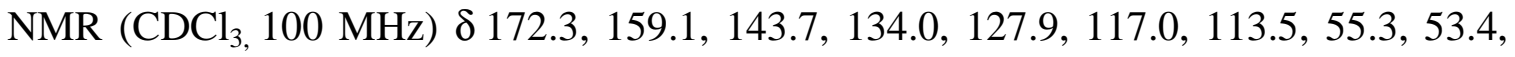
52.3, 40.6, 20.0; HRMS calcd for $\mathrm{C}_{16} \mathrm{H}_{18} \mathrm{D}_{2} \mathrm{O}_{5}[\mathrm{M}]^{+}$294.1436, found 294.1432.

\section{Concurrent Pd-Catalyzed Suzuki and Allylic Substitution Reactions Between 2- Bromo-1-methylprop-2-en-1-yl Acetate (17), Sodium Phenoxide and 4- Methoxyphenylboronic acid. To a solution of phenol $(54 \mathrm{mg}, 0.57 \mathrm{mmol})$ in THF (1 $\mathrm{mL}$ ) was added $\mathrm{NaH}$ (60\% dispersion in mineral oil, $23 \mathrm{mg}, 0.57 \mathrm{mmol}$ ) in small portions. The resulting solution was stirred at rt for $10 \mathrm{~min}$. In a separate flask, a suspension of 4-}


methoxyphenyl boronic acid $(87 \mathrm{mg}, 0.57 \mathrm{mmol}$ ) and cesium fluoride (395 mg, $2.6 \mathrm{mmol}$ ) in THF $(1 \mathrm{~mL})$ was stirred for $10 \mathrm{~min}$ at $\mathrm{rt}$ and then added to the first flask. A solution of 2-bromo-1-methylprop-2-en-1-yl acetate (17) $(100 \mathrm{mg}, 0.52 \mathrm{mmol})$ in THF (1 mL) was added, followed quickly by $\left(\mathrm{PPh}_{3}\right)_{4} \mathrm{Pd}(3 \mathrm{mg}, 0.026 \mathrm{mmol})$ and the mixture was stirred at rt for $6 \mathrm{~h}$. The reaction was quenched with $\mathrm{H}_{2} \mathrm{O}$ and diluted with pentane. The organic layer was separated, dried over anhydrous $\mathrm{MgSO}_{4}$, filtered and the solvent removed in vасио. Purification by flash chromatography (80:20 pentane/ether) afforded $32 \mathrm{mg}$ of $\mathbf{1 8}$ (26\%), $5 \mathrm{mg}$ of $\mathbf{2 0}(7 \%)$ and $16 \mathrm{mg}$ of a mixture of $\mathbf{1 8}$ and $\mathbf{1 9}(13 \%)$.

Compound $18{ }^{1} \mathrm{H}$ NMR $\left(400 \mathrm{MHz}, \mathrm{CDCl}_{3}\right) \delta$ 7.36-7.27 (m, 4H), 7.16-7.12 (m, $\left.1 \mathrm{H}\right)$, 7.04-6.95 (m, 5H), $4.86(\mathrm{q}, J=6.2 \mathrm{~Hz}, 1 \mathrm{H}), 4.47(\mathrm{~s}, 1 \mathrm{H}), 4.04(\mathrm{~s}, 1 \mathrm{H}), 1.67(\mathrm{~d}, J=6.2 \mathrm{~Hz}$, $3 \mathrm{H})$; HRMS calcd for $\mathrm{C}_{16} \mathrm{H}_{16} \mathrm{O}_{2}[\mathrm{M}]^{+} 240.1150$, found 240.1160 .

Compound $20{ }^{1} \mathrm{H}$ NMR $\left(400 \mathrm{MHz}, \mathrm{CDCl}_{3}\right) \delta$ 7.36-7.32 (m, 2H), 7.13-7.06 (m, 3H), $6.32(\mathrm{dd}, J=17.2 \mathrm{~Hz}, J=10.8 \mathrm{~Hz}, 1 \mathrm{H}), 5.69(\mathrm{~d}, J=17.2 \mathrm{~Hz}, 1 \mathrm{H}), 5.21(\mathrm{~d}, J=10.8 \mathrm{~Hz}$, $1 \mathrm{H}), 4.55(\mathrm{~s}, 1 \mathrm{H}), 4.34(\mathrm{~s}, 1 \mathrm{H})$; HRMS calcd for $\mathrm{C}_{10} \mathrm{H}_{10} \mathrm{O}[\mathrm{M}]^{+}$146.0732, found 146.0730. This data is consistent with the literature data ${ }^{9}$

Mixture of 18 and $\boldsymbol{E}$ and $\boldsymbol{Z}$ isomers of 19 in the ratio 18:19, 1.0:0.62, ${ }^{1} \mathrm{H}$ NMR (400 $\left.\mathrm{MHz}, \mathrm{CDCl}_{3}\right) \delta 7.34-6.88(\mathrm{~m}, 30 \mathrm{H}), 5.57(\mathrm{q}, J=6.8 \mathrm{~Hz}, 1 \mathrm{H})(19), 5.21(\mathrm{q}, J=7.2 \mathrm{~Hz}$, 1H) (19), $4.86(\mathrm{q}, J=6.4 \mathrm{~Hz}, 1 \mathrm{H})(\mathbf{1 8}), 4.68(\mathrm{~s}, 2 \mathrm{H})(\mathbf{1 9}), 4.49(\mathrm{~s}, 2 \mathrm{H})(\mathbf{1 9}), 4.47(\mathrm{~s}, 1 \mathrm{H})$ (18), $4.04(\mathrm{~s}, 1 \mathrm{H})(\mathbf{1 8}), 1.76(\mathrm{~d}, J=7.2 \mathrm{~Hz}, 3 \mathrm{H})(\mathbf{1 9}), 1.68(\mathrm{~d}, J=6.4 \mathrm{~Hz}, 3 \mathrm{H})(\mathbf{1 8}), 1.64$ (d, $J=7.2 \mathrm{~Hz}, 3 \mathrm{H})(\mathbf{1 9})$.

Pd-Catalyzed Sonogashira reaction with 2-bromoprop-2-en-1-yl acetate (7). Preparation of 21.

To a solution of 7 ( $83 \mathrm{mg}, 0.46 \mathrm{mmol})$ in THF ( $3 \mathrm{~mL})$ was added in sequence copper iodide (9 mg, $0.046 \mathrm{mmol})$, triethylamine $(94 \mathrm{mg}, 0.13 \mathrm{~mL}, 0.92 \mathrm{mmol}), \mathrm{Pd}\left(\mathrm{PPh}_{3}\right)_{4}(27$ $\mathrm{mg} 0.023 \mathrm{mmol})$ and TMS-acetylene $(64 \mathrm{mg}, 0.65 \mathrm{mmol})$. The reaction mixture was stirred at $\mathrm{rt}$ for $12 \mathrm{~h}$ after which the solvent was removed in vacuo. Purification of the resulting residue by flash chromatography (90:10 pentane/ether) afforded $44 \mathrm{mg}$ of $\mathbf{2 1}$ as an oil (49\% yield, $62 \%$ based on recovered starting material) along with $18 \mathrm{mg}$ of 7 $(22 \%)$.

Compound $21{ }^{1} \mathrm{H}$ NMR (400 MHz, $\left.\mathrm{CDCl}_{3}\right) \delta 5.57(\mathrm{~s}, 1 \mathrm{H}), 5.51(\mathrm{~s}, 1 \mathrm{H}), 4.59(\mathrm{~s}, 2 \mathrm{H})$, $2.12(\mathrm{~s}, 3 \mathrm{H}), 0.20(\mathrm{~s}, 9 \mathrm{H}) ;{ }^{13} \mathrm{C} \mathrm{NMR}\left(\mathrm{CDCl}_{3}, 100 \mathrm{MHz}\right) \delta 170.3,126.6,123.2,102.2,96.1$, 65.4, 20.8, 0.2; HRMS calcd for $\mathrm{C}_{10} \mathrm{H}_{16} \mathrm{O}_{2} \mathrm{Si}[\mathrm{M}]^{+}$196.0918, found 196.0920.

Pd-Catalyzed Suzuki Cross-Coupling of Template 11. (Products 22, 23, 24 and 25)

A suspension of 4-methoxyphenyl boronic acid $(66 \mathrm{mg}, 0.436 \mathrm{mmol})$ and cesium fluoride (332 mg, $2.18 \mathrm{mmol})$ in DMF $(4 \mathrm{~mL})$ was stirred for $10 \mathrm{~min}$ at $\mathrm{rt}$. To this was added $\left(\mathrm{PPh}_{3}\right)_{4} \mathrm{Pd}(25 \mathrm{mg}, 0.022 \mathrm{mmol})$ followed by a DMF (2 mL) solution of $11(79 \mathrm{mg}, 0.44$ mmol) and the reaction mixture was stirred at $65{ }^{\circ} \mathrm{C}$ for $6 \mathrm{~h}$. The reaction mixture was cooled to $\mathrm{rt}$ and then water was added $(2 \mathrm{~mL})$. The resultant solution was extracted with ether $(4 \times 4 \mathrm{~mL})$ and the organic component was separated, dried over anhydrous $\mathrm{MgSO}_{4}$, filtered and the solvent removed in vacuo. The residue was then purified by flash chromatography (90:10 pentane/ether) to afford $14 \mathrm{mg}$ of an inseparable mixture of $\mathbf{2 2}$ and $\mathbf{2 3}$ as an oil (13\% yield, based on 11) and $24 \mathrm{mg}$ of an inseparable mixture of $\mathbf{2 4}$ and $\mathbf{2 5}$ as an oil (26\% yield, based on 11). 
Inseparable mixture of 22 and 23. ${ }^{1} \mathrm{H} \mathrm{NMR}\left(400 \mathrm{MHz}, \mathrm{CDCl}_{3}\right) \delta 7.38(\mathrm{~d}, J=8.8 \mathrm{~Hz}$, $4 \mathrm{H}), 7.14(\mathrm{~d}, J=8.4 \mathrm{~Hz}, 4 \mathrm{H}), 6.81-6.84(\mathrm{~m}, 8 \mathrm{H}), 5.41(\mathrm{~s}, 1 \mathrm{H}), 4.94(\mathrm{~s}, 1 \mathrm{H}), 3.79(\mathrm{~s}, 6 \mathrm{H})$, $3.78(\mathrm{~s}, 6 \mathrm{H}), 3.75(\mathrm{~s}, 2 \mathrm{H}) ;{ }^{13} \mathrm{C} \mathrm{NMR}\left(\mathrm{CDCl}_{3}, 100 \mathrm{MHz}\right) 159.0,158.0,146.4,133.3,131.7$, 129.8, 127.3 113.8, 113.6, 112.7, 55.4 (two coincident peaks), 40.8; HRMS calcd for $\mathrm{C}_{17} \mathrm{H}_{16} \mathrm{D}_{2} \mathrm{O}_{2}[\mathrm{M}]^{+}$256.1430, found 256.1432.

Inseparable mixture of 24 and 25. ${ }^{1} \mathrm{H}$ NMR $\left(400 \mathrm{MHz}, \mathrm{CDCl}_{3}\right) \delta 7.38(\mathrm{~d}, J=8.4 \mathrm{~Hz}$, 4H), 6.89 (d, $J=8.4 \mathrm{~Hz}, 4 \mathrm{H}), 5.49(\mathrm{~s}, 1 \mathrm{H}), 5.28(\mathrm{~s}, 1 \mathrm{H}), 4.96(\mathrm{~s}, 2 \mathrm{H}), 3.82(\mathrm{~s}, 6 \mathrm{H}), 2.09$ (s, $6 \mathrm{H}) ;{ }^{13} \mathrm{C} \mathrm{NMR}\left(\mathrm{CDCl}_{3}, 100 \mathrm{MHz}\right) \delta 170.8,159.6,141.2,130.6,124.9,114.7,113.8,65.8$, 55.1, 20.4; HRMS calcd for $\mathrm{C}_{12} \mathrm{H}_{12} \mathrm{D}_{2} \mathrm{O}_{3}[\mathrm{M}]^{+}$208.1068, found 208.1052.

Dimethyl (2-chloroprop-2-en-1-yl)(methyl)malonate (34b). To a suspension of $\mathrm{NaH}$ (26 mg, $0.65 \mathrm{mmol}, 60 \%$ dispersion in mineral oil) in THF (1 mL) was added dimethyl methylmalonate $(95 \mathrm{mg}, 0.65 \mathrm{mmol})$ in THF $(2 \mathrm{~mL})$. The resulting solution was stirred for $10 \mathrm{~min}$ at $\mathrm{rt}$ and a solution of $\mathbf{3 3 b}(79 \mathrm{mg}, 0.59 \mathrm{mmol})$ in THF (2 mL) was added followed by $\left(\mathrm{PPh}_{3}\right)_{4} \mathrm{Pd}(35 \mathrm{mg}, 0.03 \mathrm{mmol})$. After stirring for $21 \mathrm{~h}$ the reaction was quenched with $\mathrm{H}_{2} \mathrm{O}$ and partitioned between water and ether. The organic layer was separated, dried over anhydrous $\mathrm{MgSO}_{4}$, filtered and the solvent was removed in vacuo. Purification by flash chromatography (80:20 pentane/ether) afforded $94 \mathrm{mg}$ of $\mathbf{3 3 b}$ as an oil (72\% yield). ${ }^{1} \mathrm{H}$ NMR (400 MHz, $\left.\mathrm{CDCl}_{3}\right) \delta 5.32(\mathrm{~s}, 1 \mathrm{H}), 5.22(\mathrm{~s}, 1 \mathrm{H}), 3.75(\mathrm{~s}, 6 \mathrm{H})$, 3.05 (s, 2H), 1.49 (s, 3H).

This data is consistent with the literature data ${ }^{8}$

Treatment of 2-iodoprop-2-en-1-yl acetate (33a) with stoichiometric palladium. Preparation of 35.

To a solution of $\mathrm{Pd}\left(\mathrm{PPh}_{3}\right)_{4}(256 \mathrm{mg}, 0.22 \mathrm{mmol})$ in THF $(5 \mathrm{~mL})$ was added a solution of 33a $(50 \mathrm{mg}, 0.22 \mathrm{mmol})$ in THF (1 mL) via syringe. The color of the solution changed from orange to deep red and after $30 \mathrm{~min}$ a precipitate formed. Filtration and washing with pentane afforded $82 \mathrm{mg}$ of 35 as a tan colored solid (42\%). ${ }^{1} \mathrm{H}$ NMR (400 MHz, $\left.\mathrm{CDCl}_{3}\right), \delta 7.75-7.33(\mathrm{~m}, 30 \mathrm{H}), 4.88(\mathrm{~m}, 1 \mathrm{H}), 4.70(\mathrm{~m}, 1 \mathrm{H}), 3.51(\mathrm{~s}, 2 \mathrm{H}), 1.72(\mathrm{~s}, 3 \mathrm{H}) ;{ }^{13} \mathrm{C}$ NMR $\left(100 \mathrm{MHz}, \mathrm{CDCl}_{3}\right) \delta 160.1,135.4,135.3,135.1,132.1,131.8,131.7,131.5,130.2$, 128.6, 128.4, 127.9, 128.8, 127.6, 113.9, 67.5, 20.4; MS (MALDI) showed a peak at 892.5 corresponding to $\mathrm{M}+\mathrm{HCl}$.

Dimethyl (3-bromo-1,1-dideuterioprop-2-en-1-yl)(methyl) malonate (36). Inseparable Mixture of $\boldsymbol{E}$ and $\boldsymbol{Z}$ Isomers. To a solution of dimethyl methylmalonate (60 $\mathrm{mg}, 0.41 \mathrm{mmol})$ in THF (3 mL) was added $\mathrm{NaH}(17 \mathrm{mg}, 0.41 \mathrm{mmol}$ of a $60 \%$ dispersion in mineral oil) in small batches. The resulting solution was stirred for $10 \mathrm{~min}$. at $\mathrm{rt}$ and then $\left(\mathrm{PPh}_{3}\right)_{4} \mathrm{Pd}(22 \mathrm{mg}, 0.019 \mathrm{mmol})$ was added followed immediately by a solution of $37(68 \mathrm{mg}, 0.38 \mathrm{mmol})$ in THF $(1 \mathrm{~mL})$. The reaction was stirred at $\mathrm{rt}$ for $72 \mathrm{~h}$ after which it was quenched with $\mathrm{H}_{2} \mathrm{O}$ and extracted with methylene chloride. The organic layer was separated, dried over anhydrous $\mathrm{MgSO}_{4}$, filtered and the solvent was removed in vacuo. Purification by flash chromatography (80:20 pentane/ether) afforded $37 \mathrm{mg}$ of $\mathbf{3 6}$ as an oil (36\% yield, $71 \%$ yield based on recovered starting material) along with $33 \mathrm{mg}$ of 37 (49\% recovery). Inseparable mixture of $\boldsymbol{E}$ and $\boldsymbol{Z}$ isomers of $36 .{ }^{1} \mathrm{H}$ NMR (400 MHz, $\left.\mathrm{CDCl}_{3}\right), 6.32(\mathrm{~d}, J=7.2 \mathrm{~Hz}, 1 \mathrm{H}), 6.16-6.11(\mathrm{~m}, 2 \mathrm{H}), 6.05(\mathrm{~d}, J=7.2$ 
$\mathrm{Hz}, 1 \mathrm{H}), 3.73(\mathrm{~s}, 12 \mathrm{H}), 1.44(\mathrm{~s}, 3 \mathrm{H}), 1.41(\mathrm{~s}, 3 \mathrm{H}) ;{ }^{13} \mathrm{C} \mathrm{NMR}\left(\mathrm{CDCl}_{3}, 100 \mathrm{MHz}\right) \delta 172.0(2$ coincident peaks), 133.4, 129.2, 111.3, 108.3, 53.0 (2 coincident peaks), 52.7 (2 coincident peaks), 20.0 (2 coincident peaks). ( $\mathrm{CD}_{2}$ signal not observed); HRMS calcd for $\mathrm{C}_{9} \mathrm{H}_{11} \mathrm{D}_{2} \mathrm{BrO}_{4}[\mathrm{M}]^{+}$266.0123, found 266.0120.

(2Z)-1-(1,1-Dideuterio)-3-(4-methoxyphenyl)prop-2-en-1-yl acetate (38). A suspension of 4-methoxyphenyl boronic acid (69 $\mathrm{mg}, 0.46 \mathrm{mmol})$ and cesium fluoride (315 mg, $2.07 \mathrm{mmol})$ in THF (3 mL) was stirred for $10 \mathrm{~min}$ at $\mathrm{rt}$. A THF (2 mL) solution containing $\left(\mathrm{PPh}_{3}\right)_{4} \mathrm{Pd}(24 \mathrm{mg}, 0.021 \mathrm{mmol})$ and $37(75 \mathrm{mg}, 0.41 \mathrm{mmol})$ was then added and the reaction mixture was stirred at $60{ }^{\circ} \mathrm{C}$ for $7 \mathrm{~h}$. The reaction mixture was diluted with pentane, filtered and the solvent removed in vacuo. The residue was then purified by flash chromatography (90:10 pentane/ether) to afford $59 \mathrm{mg}$ of $\mathbf{3 8}$ as an oil (69\% yield). ${ }^{1} \mathrm{H}$ NMR $\left(400 \mathrm{MHz}, \mathrm{CDCl}_{3}\right) \delta 7.18(\mathrm{~d}, J=8.4 \mathrm{~Hz}, 2 \mathrm{H}), 6.89(\mathrm{~d}, J=8.4 \mathrm{~Hz}, 2 \mathrm{H}), 6.61(\mathrm{~d}$, $J=11.6 \mathrm{~Hz}, 1 \mathrm{H}), 5.72(\mathrm{~d}, J=11.6 \mathrm{~Hz}, 1 \mathrm{H}), 3.82(\mathrm{~s}, 3 \mathrm{H}), 2.09(\mathrm{~s}, 3 \mathrm{H}) ;{ }^{13} \mathrm{C} \mathrm{NMR}\left(\mathrm{CDCl}_{3}\right.$, $100 \mathrm{MHz}) \delta 170.9,159.1,132.7,130.1,128.7,123.9,114.0,61.0$ (m), 55.7, 21.0; HRMS calcd for $\mathrm{C}_{12} \mathrm{H}_{12} \mathrm{D}_{2} \mathrm{O}_{3}[\mathrm{M}]^{+}$208.1068, found 208.1069.

(4E)-(3-Deuterio)-5-(4-methoxyphenyl)penta-2,4-diene-1-yl acetate (40). Inseparable Mixture of $2 \boldsymbol{E}$ and $2 Z$ Isomers. A suspension of 4-methoxyphenyl boronic acid (24 mg, $0.16 \mathrm{mmol})$ and cesium fluoride $(111 \mathrm{mg}, 0.73 \mathrm{mmol})$ in THF (3 mL) was stirred for 10 min at rt. A THF $(2 \mathrm{~mL})$ solution containing $\left(\mathrm{PPh}_{3}\right)_{4} \mathrm{Pd}(8 \mathrm{mg}, 0.007 \mathrm{mmol})$ and 39 (30 $\mathrm{mg}, 0.146 \mathrm{mmol}$ ) was then added and the reaction mixture was stirred at $60{ }^{\circ} \mathrm{C}$ for $6 \mathrm{~h}$. The reaction mixture was diluted with pentane, filtered and the solvent removed in vacuo. The residue was then purified by flash chromatography ( $90: 10$ pentane/ether) to afford 22 $\mathrm{mg}$ of 40, as a mixture of $2 E$ and $2 Z$ Isomers, as an oil (65\% yield). Only Major Isomer Shown. ${ }^{1} \mathrm{H}$ NMR $\left(400 \mathrm{MHz}, \mathrm{CDCl}_{3}\right) \delta$ 7.28-7.25 (m, 2H), 6.91-6.88 (m, 2H), 6.45 (d, J $=11.4 \mathrm{~Hz}, 1 \mathrm{H}), 6.18(\mathrm{~d}, J=11.4 \mathrm{~Hz}, 1 \mathrm{H}), 5.89(\mathrm{t}, J=6.3 \mathrm{~Hz}, 1 \mathrm{H}), 4.64(\mathrm{~d}, J=6.3 \mathrm{~Hz}$, $2 \mathrm{H}), 3.83(\mathrm{~s}, 3 \mathrm{H}), 2.08(\mathrm{~s}, 3 \mathrm{H}) ;{ }^{13} \mathrm{C} \mathrm{NMR}\left(\mathrm{CDCl}_{3}, 100 \mathrm{MHz}\right) \delta 170.8,158.9,131.0,130.3$, $129.8,128.2,127.4,113.8,64.9,55.3,21.0$ (signal for the carbon attached to D was not observed). HRMS calcd for $\mathrm{C}_{14} \mathrm{H}_{15} \mathrm{DO}_{3}[\mathrm{M}]^{+} 233.1162$, found 233.1160.

Pd-Catalyzed Suzuki reaction between 2-bromopropene (41), allylacetate (42) and 4methoxyphenylboronic acid. Preparation of 1-isopropenyl-4-methoxybenzene-4isopropenylphenyl methyl ether (43). A suspension of 4-methoxyphenyl boronic acid (188 $\mathrm{mg}, 1.24 \mathrm{mmol})$ and cesium fluoride $(942 \mathrm{mg}, 6.20 \mathrm{mmol})$ in THF $(5 \mathrm{~mL})$ was stirred for $10 \mathrm{~min}$ at $\mathrm{rt}$. A THF (2 mL) solution containing 2-bromopropene (41) $(150 \mathrm{mg}$, $1.24 \mathrm{mmol})$ and allyl acetate $(\mathbf{4 2})(124 \mathrm{mg}, 1.24 \mathrm{mmol})$ was added followed by $\left(\mathrm{PPh}_{3}\right)_{4} \mathrm{Pd}$ (72 mg, $0.062 \mathrm{mmol}$ ) and the reaction was warmed to $55{ }^{\circ} \mathrm{C}$ and stirred for $6 \mathrm{~h}$. The reaction was cooled to $\mathrm{rt}$, diluted with pentane, filtered and the solvent carefully removed in vacuo. The residue was then purified by flash chromatography (pentane) to afford 72 mg of 43 as a white solid (39\% yield). $\left.{ }^{1} \mathrm{H} \mathrm{NMR} \mathrm{(400} \mathrm{MHz,} \mathrm{CDCl}_{3}\right) \delta 7.44(\mathrm{~d}, J=8.8 \mathrm{~Hz}$, $2 \mathrm{H}), 6.89(\mathrm{~d}, J=8.8 \mathrm{~Hz}, 2 \mathrm{H}), 5.31(\mathrm{~s}, 1 \mathrm{H}), 5.01(\mathrm{~s}, 1 \mathrm{H}), 3.83(\mathrm{~s}, 3 \mathrm{H}), 2.15(\mathrm{~s}, 3 \mathrm{H}) ;{ }^{13} \mathrm{C}$ $\mathrm{NMR}\left(\mathrm{CDCl}_{3}, 100 \mathrm{MHz}\right) \delta 159.1,142.6,133.8,126.6,113.6,110.7,55.3,21.9$.

These data are consistent with the literature data. 


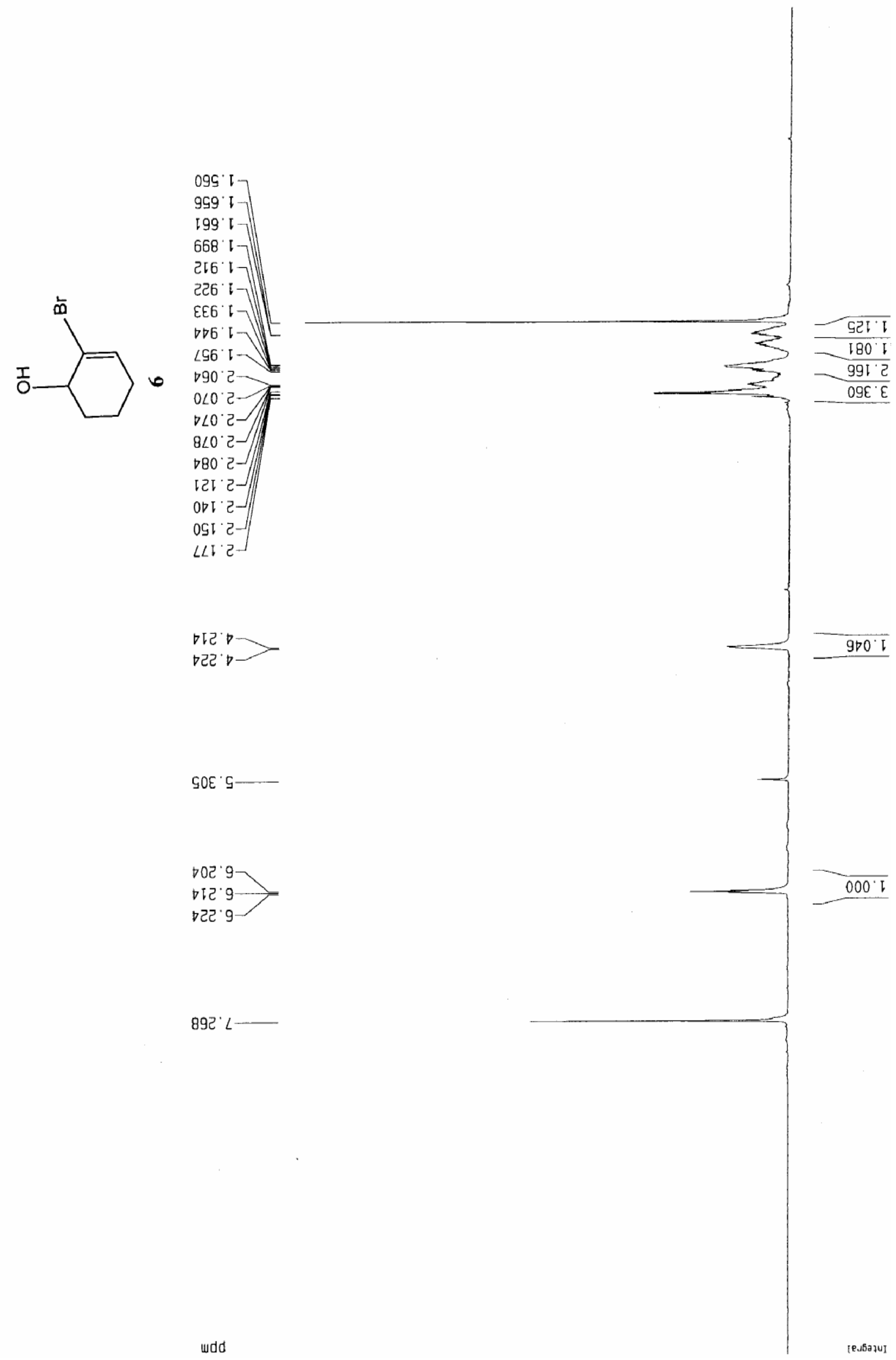




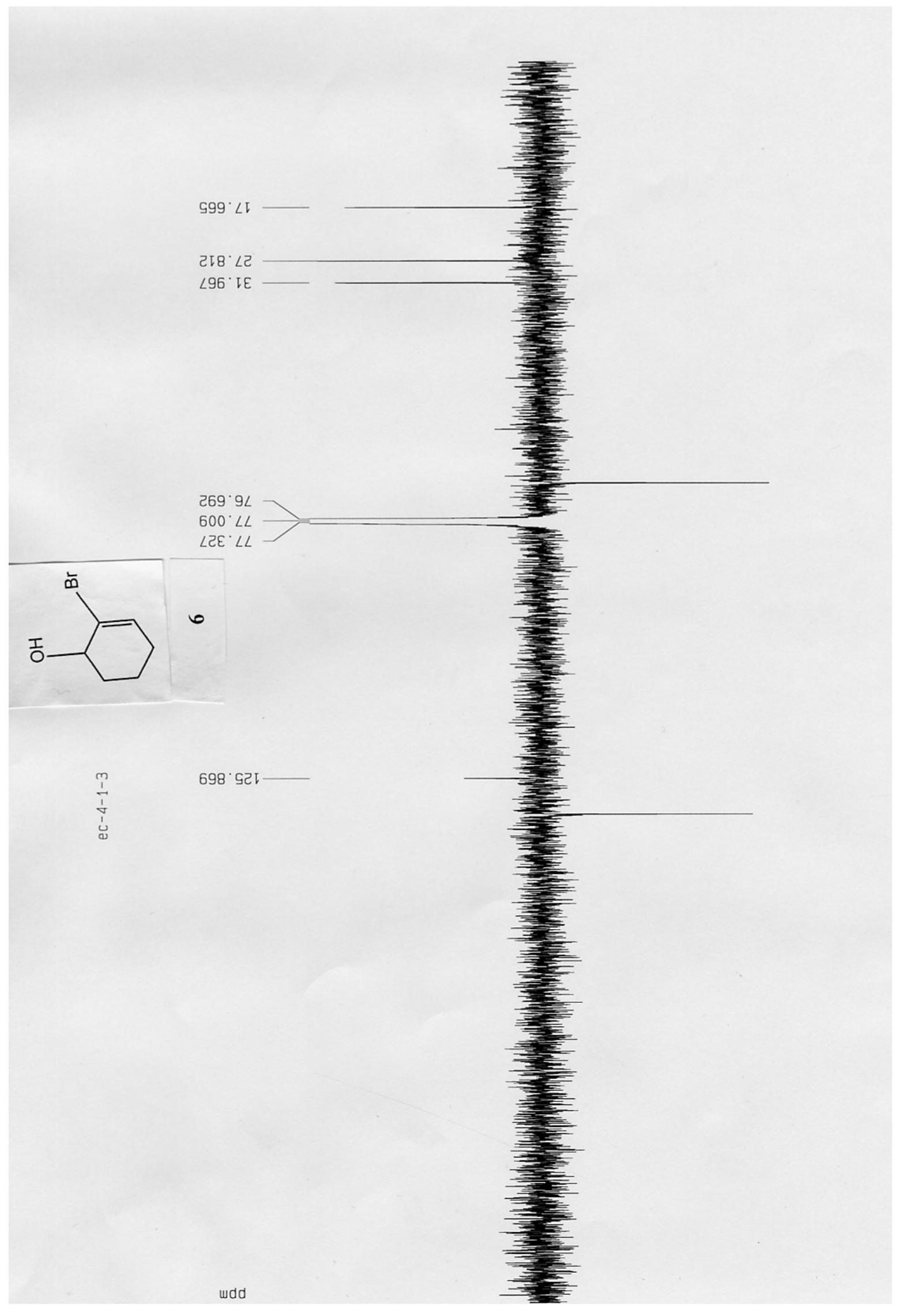




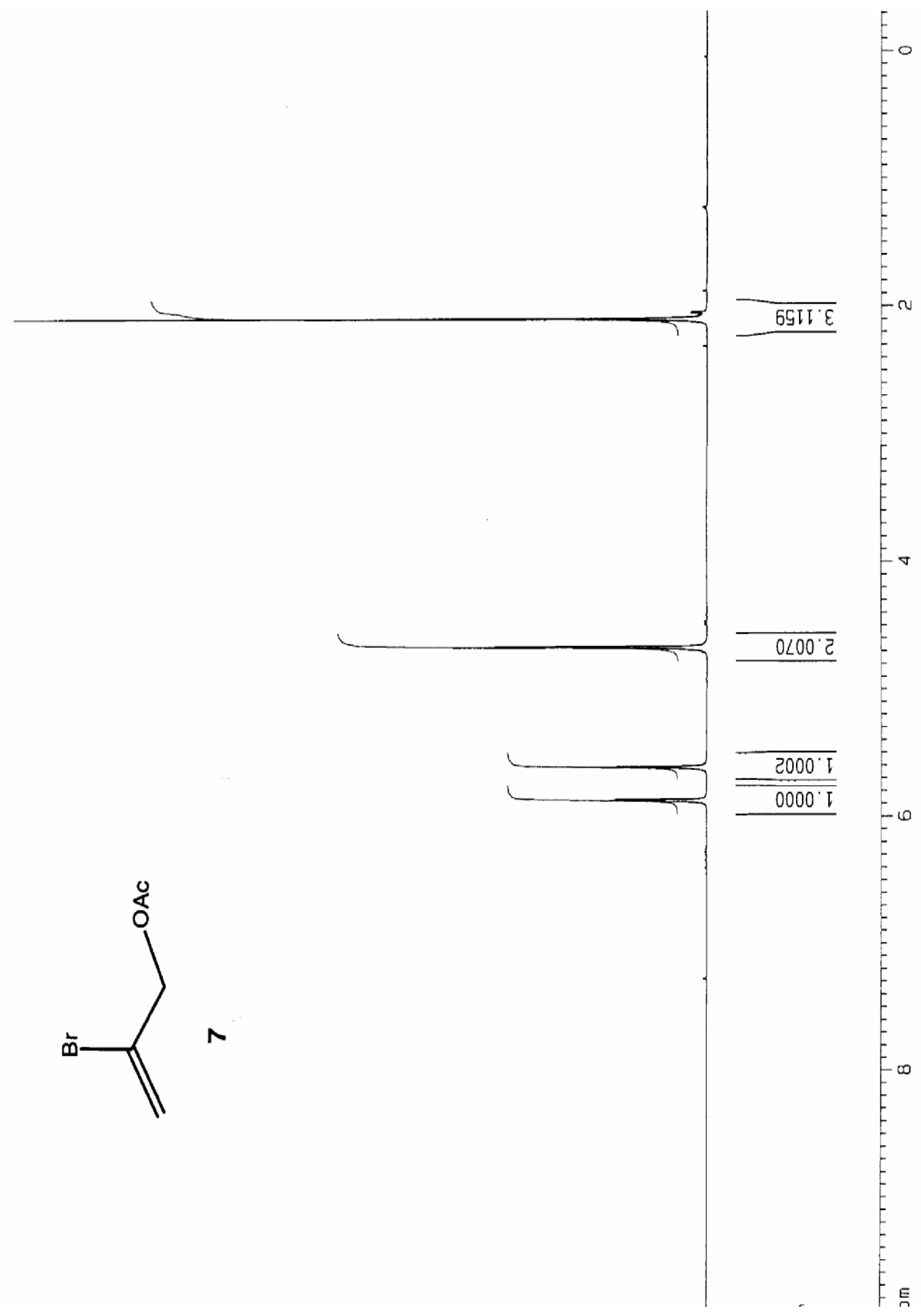




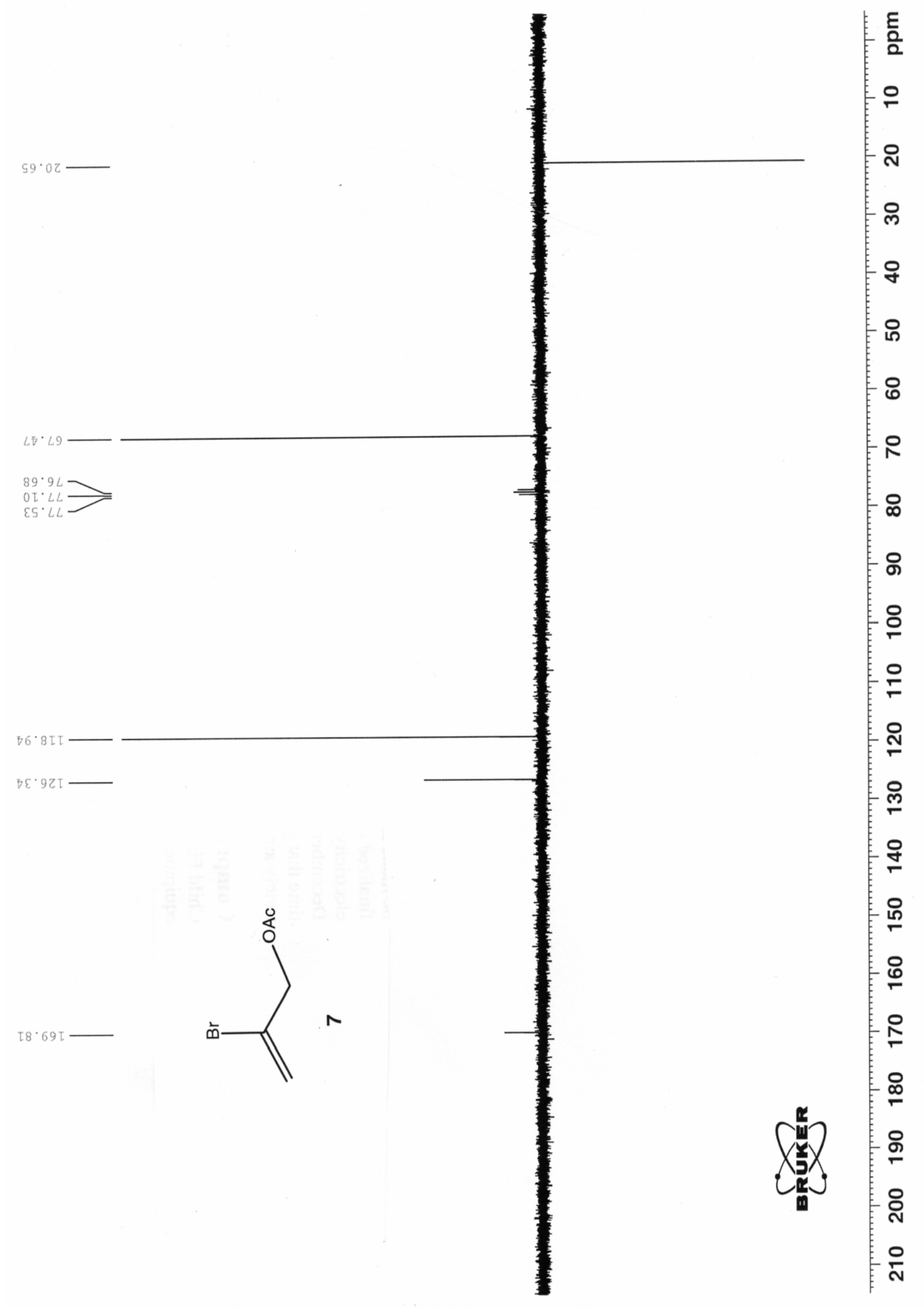




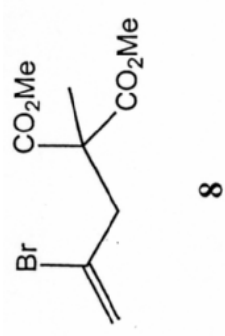

ع6เ I -

ट५ ' $\varepsilon$
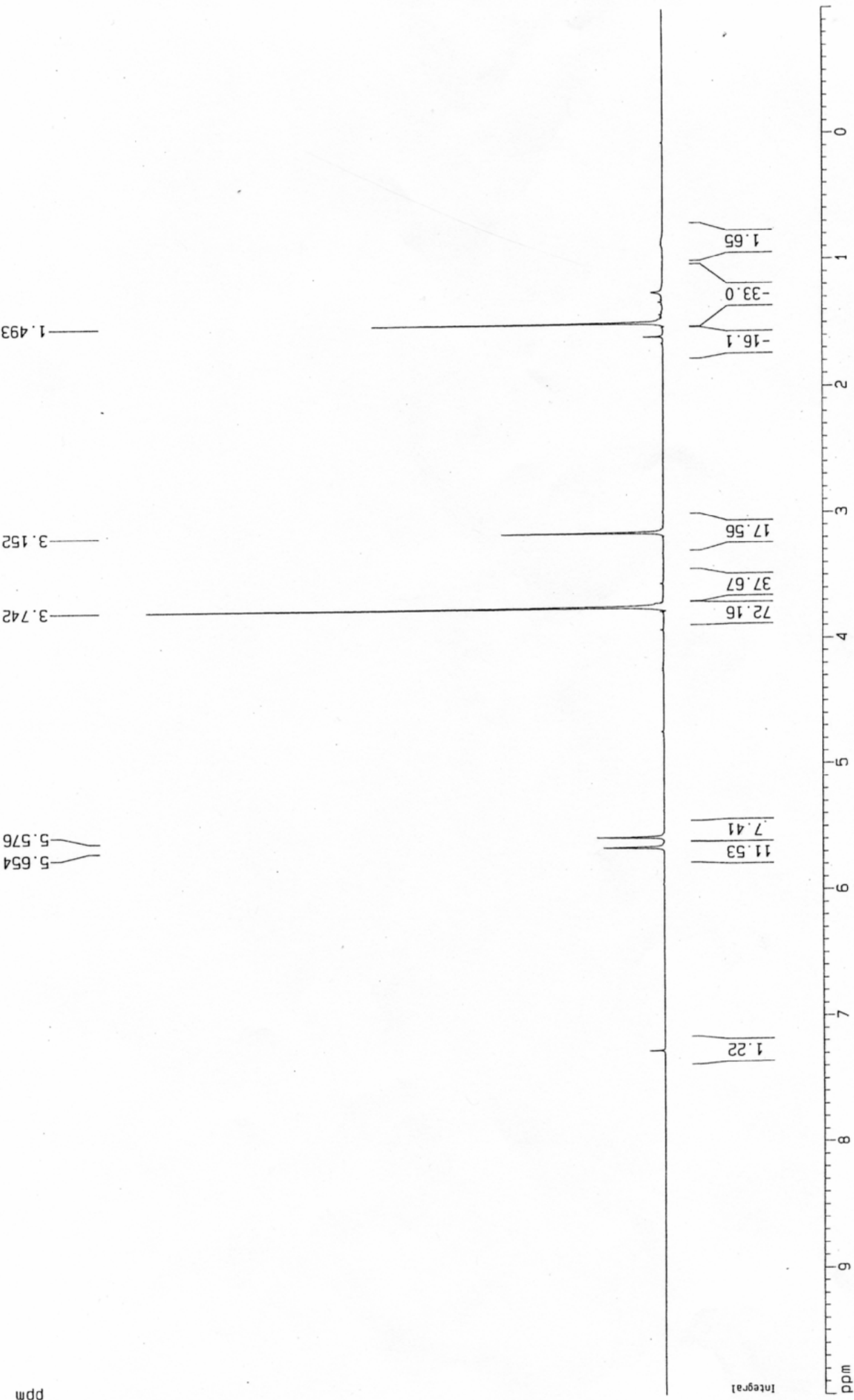

wdd 

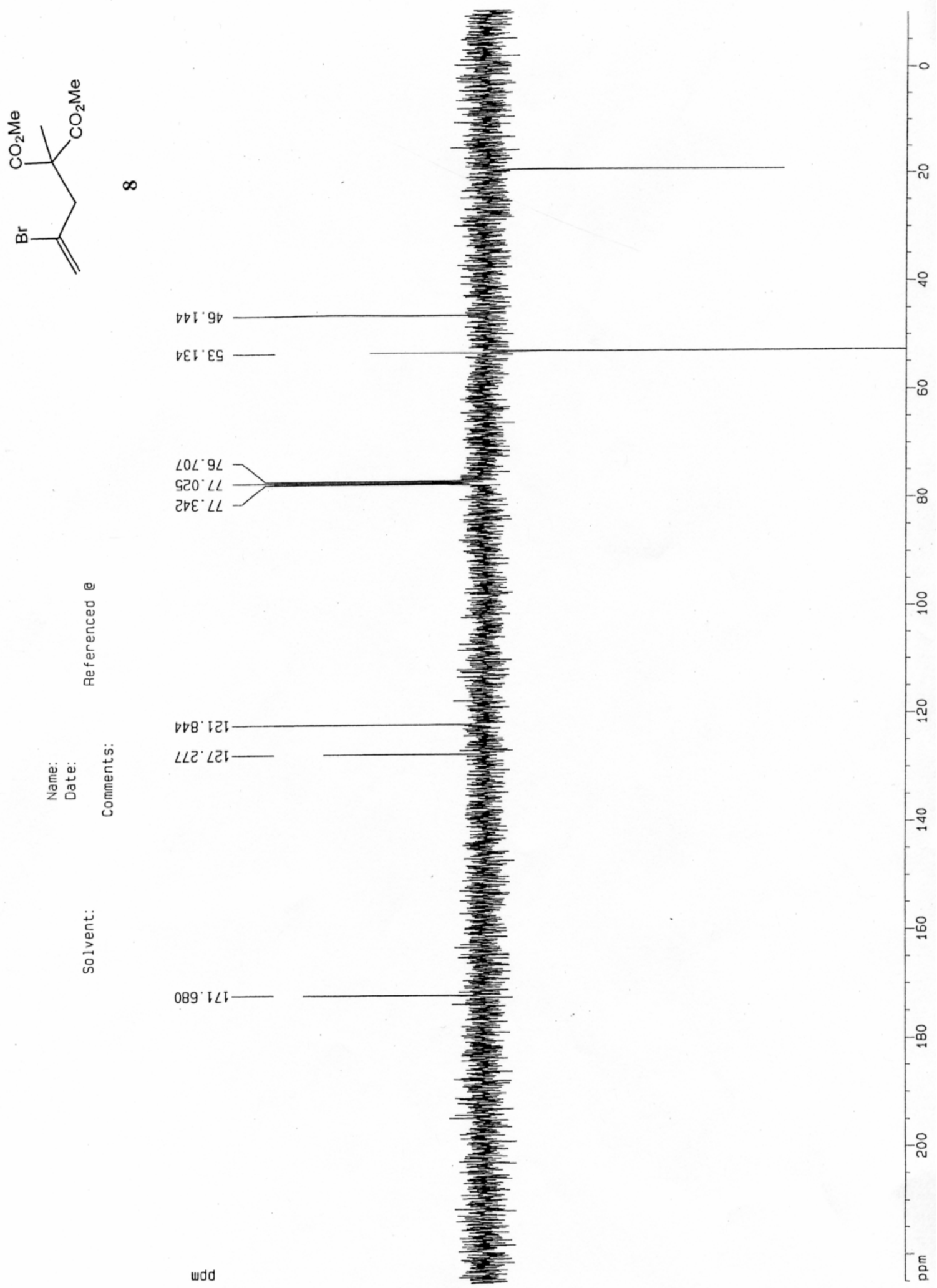


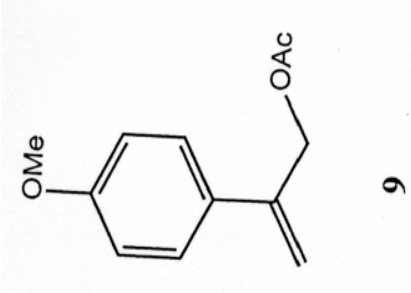

G9ट ' 1

$580^{\circ} 2-$

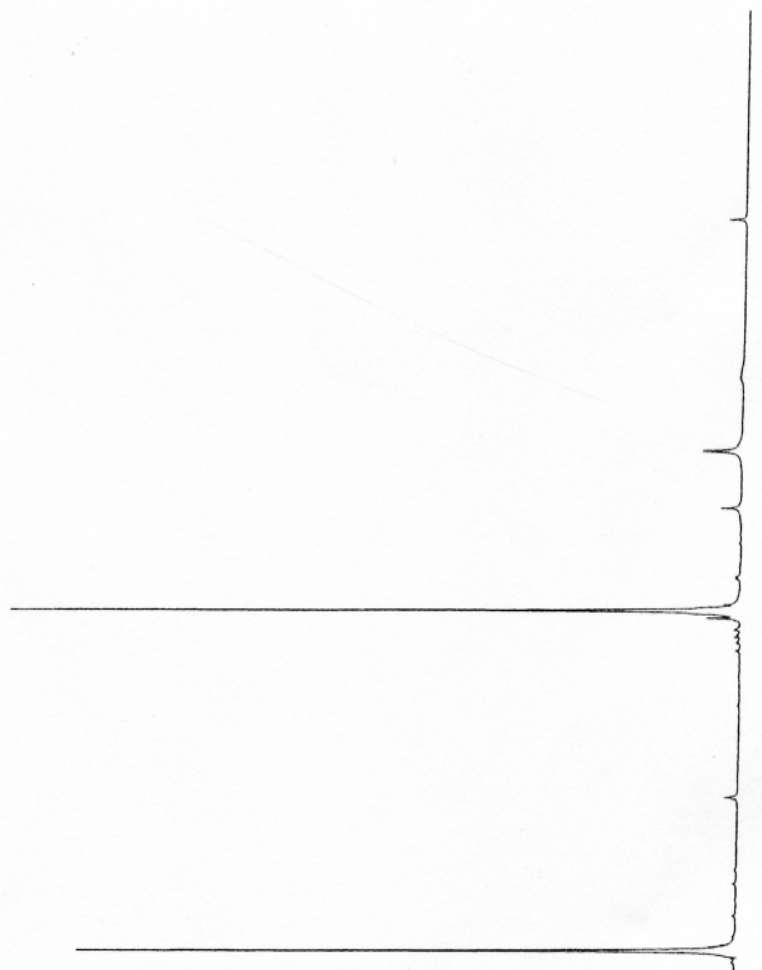

$828^{\circ} \varepsilon-$

$196^{\circ}$

$082^{\circ} \mathrm{s}$

$6 \angle D^{\circ} 9$

6L8.9-

106.9

$\angle 92^{\circ} L$

69E ' $\angle$

I6E' $L$

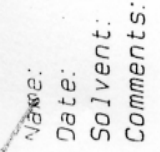

wdd

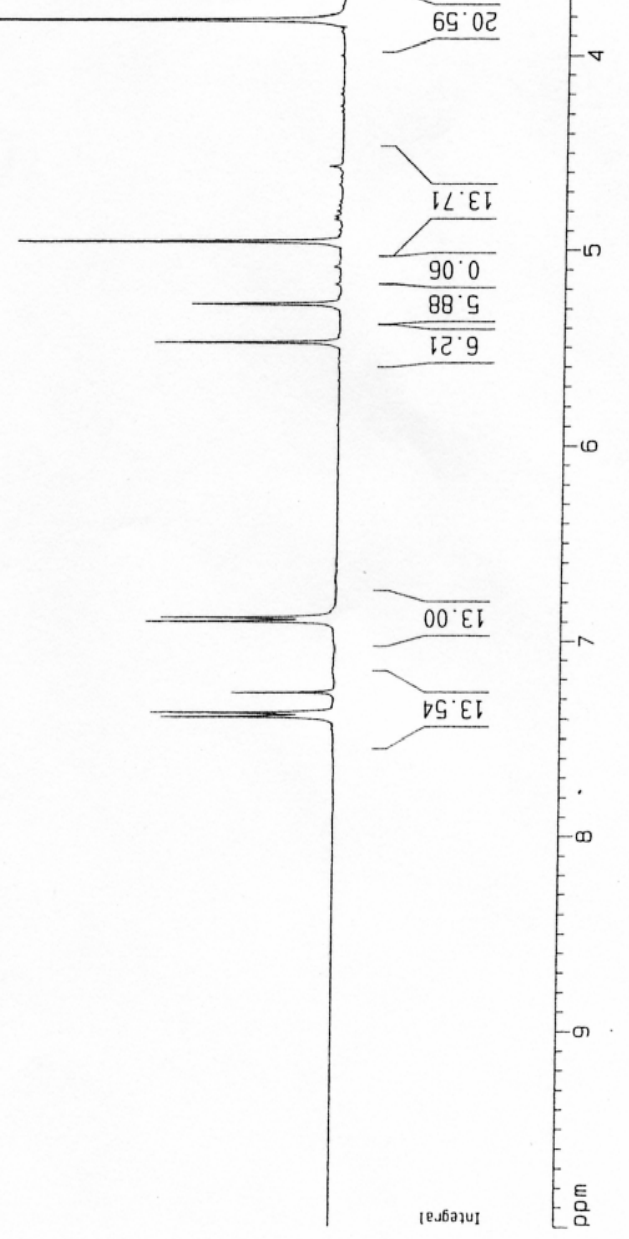



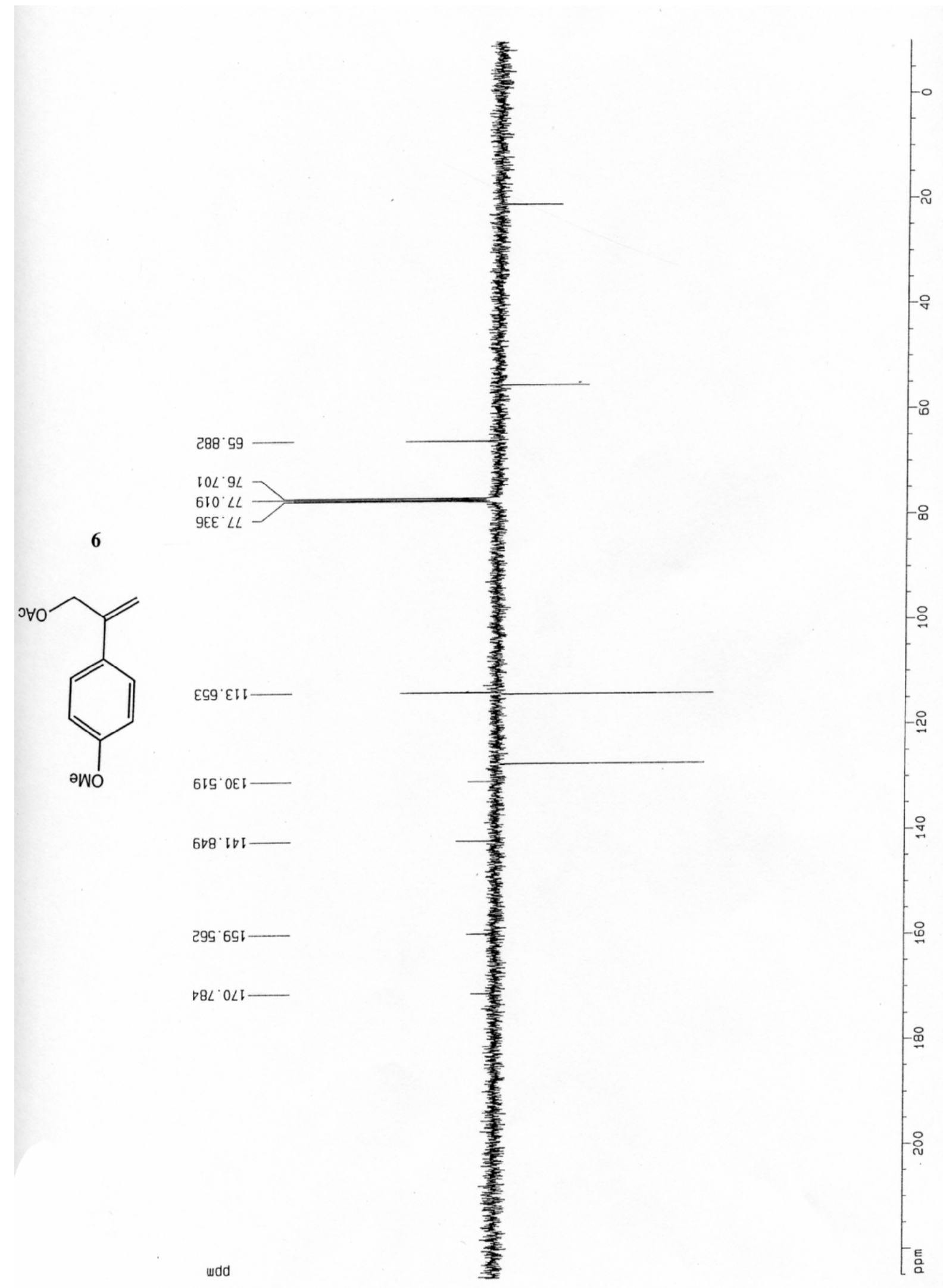


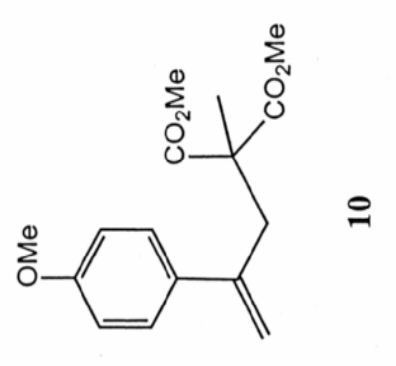

Gट60E'

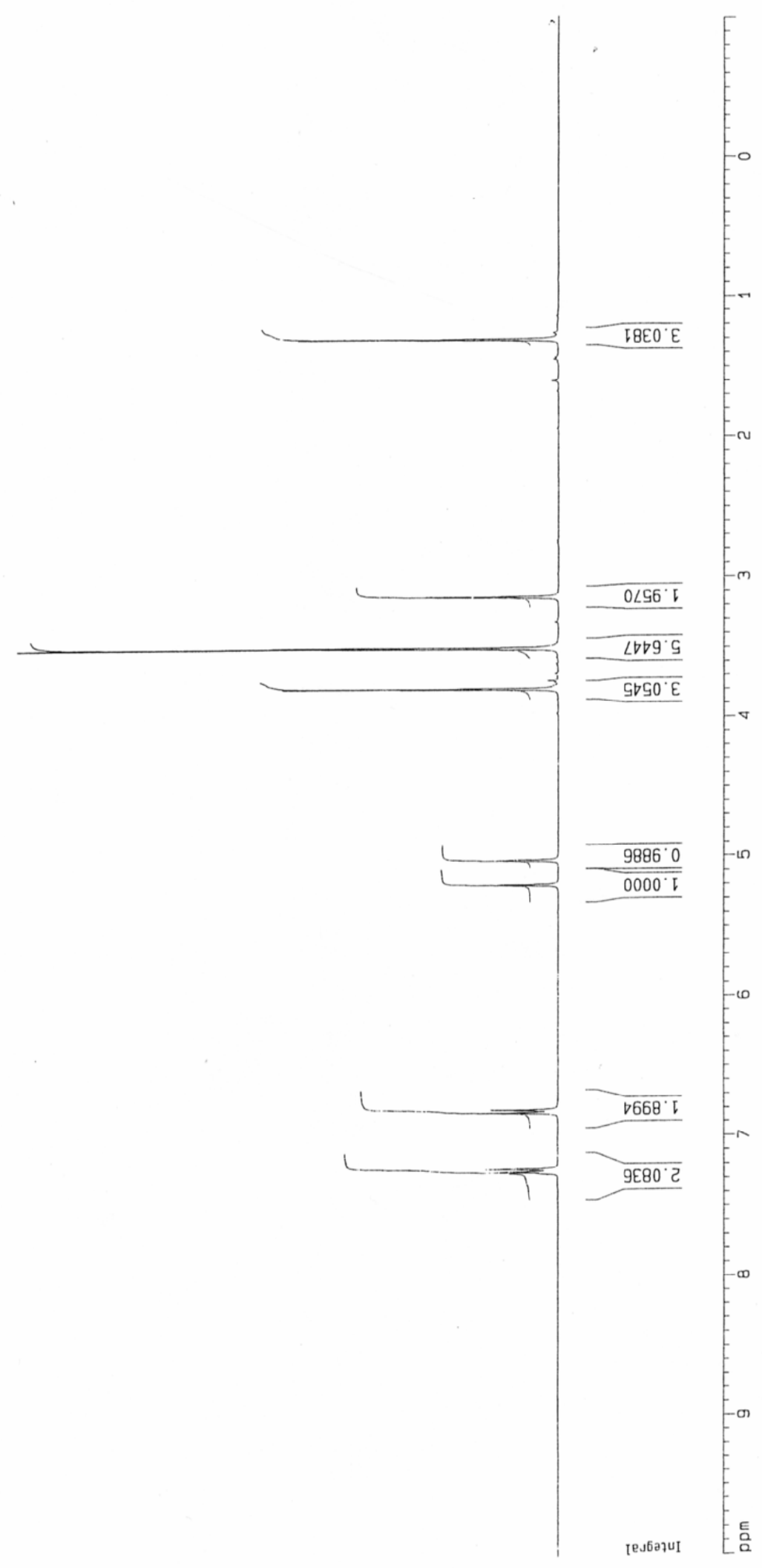



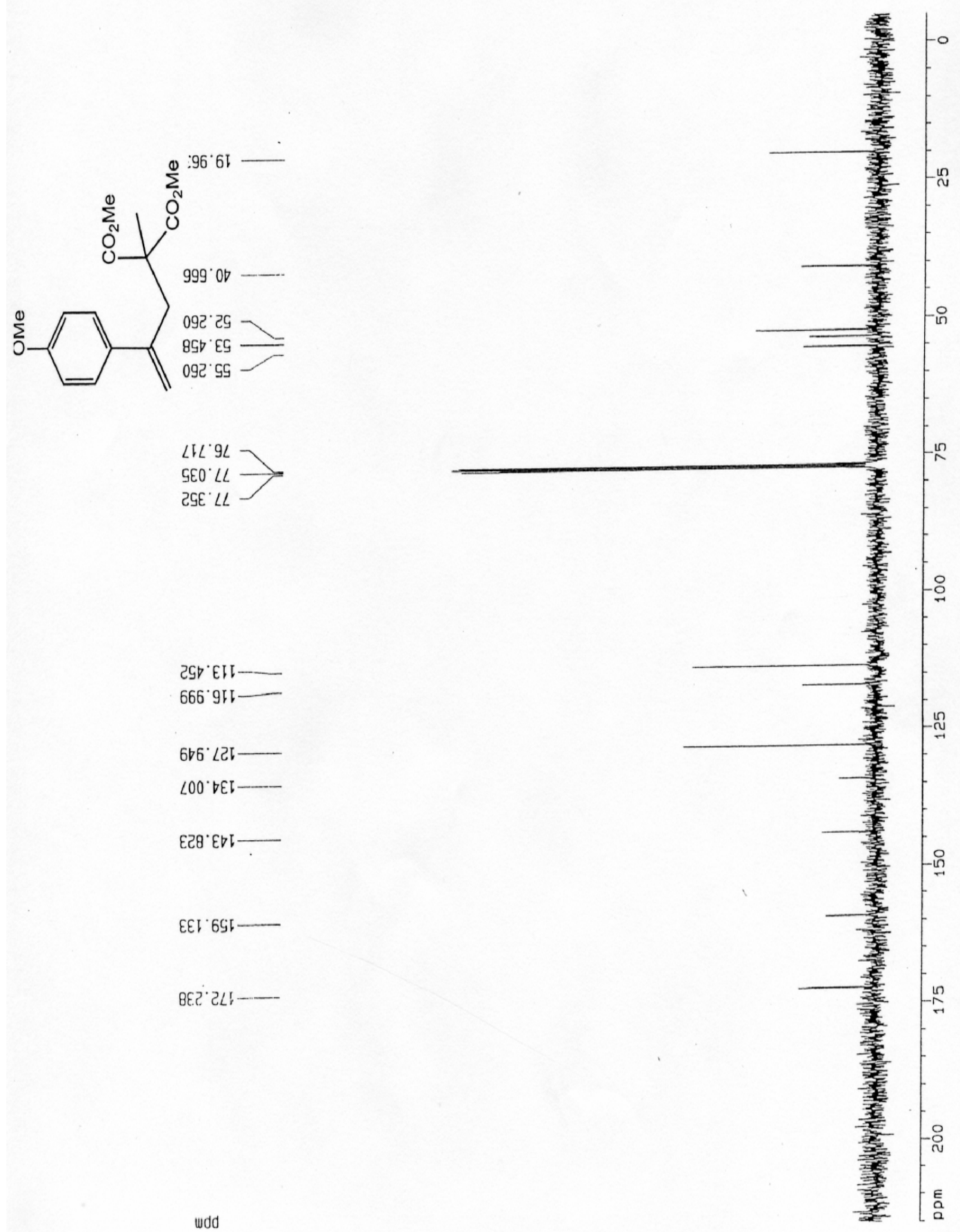

टפ" ${ }^{\circ} \mathrm{EH}-$

$666^{\circ} 915$

666. L2I-

$\angle 0^{\circ} \mathrm{B} E \mathrm{~L}-$

$\varepsilon 28^{\circ} \mathrm{Et}$

EEเ $6 \mathrm{GL}-$

BE. 'टL!-

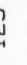




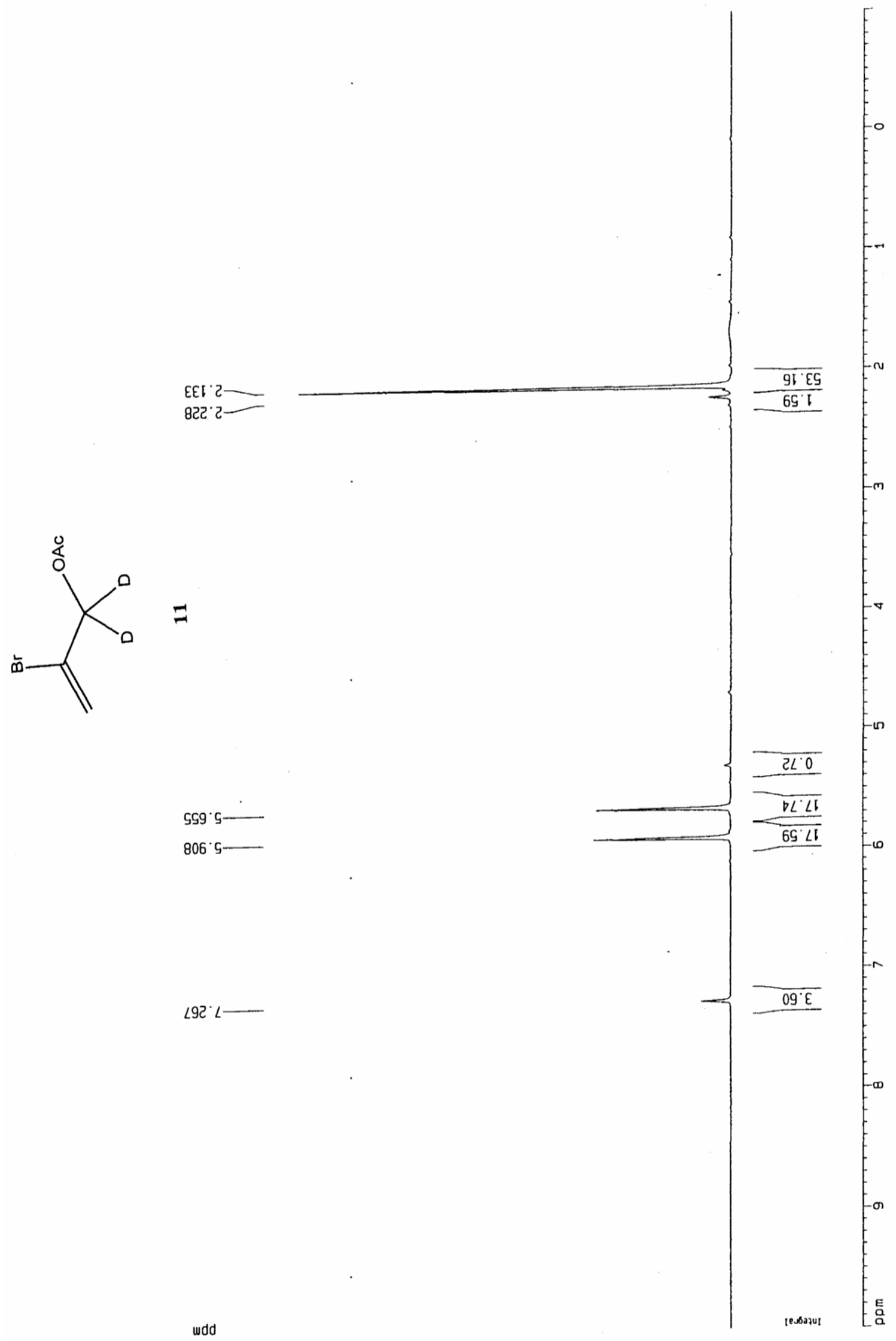




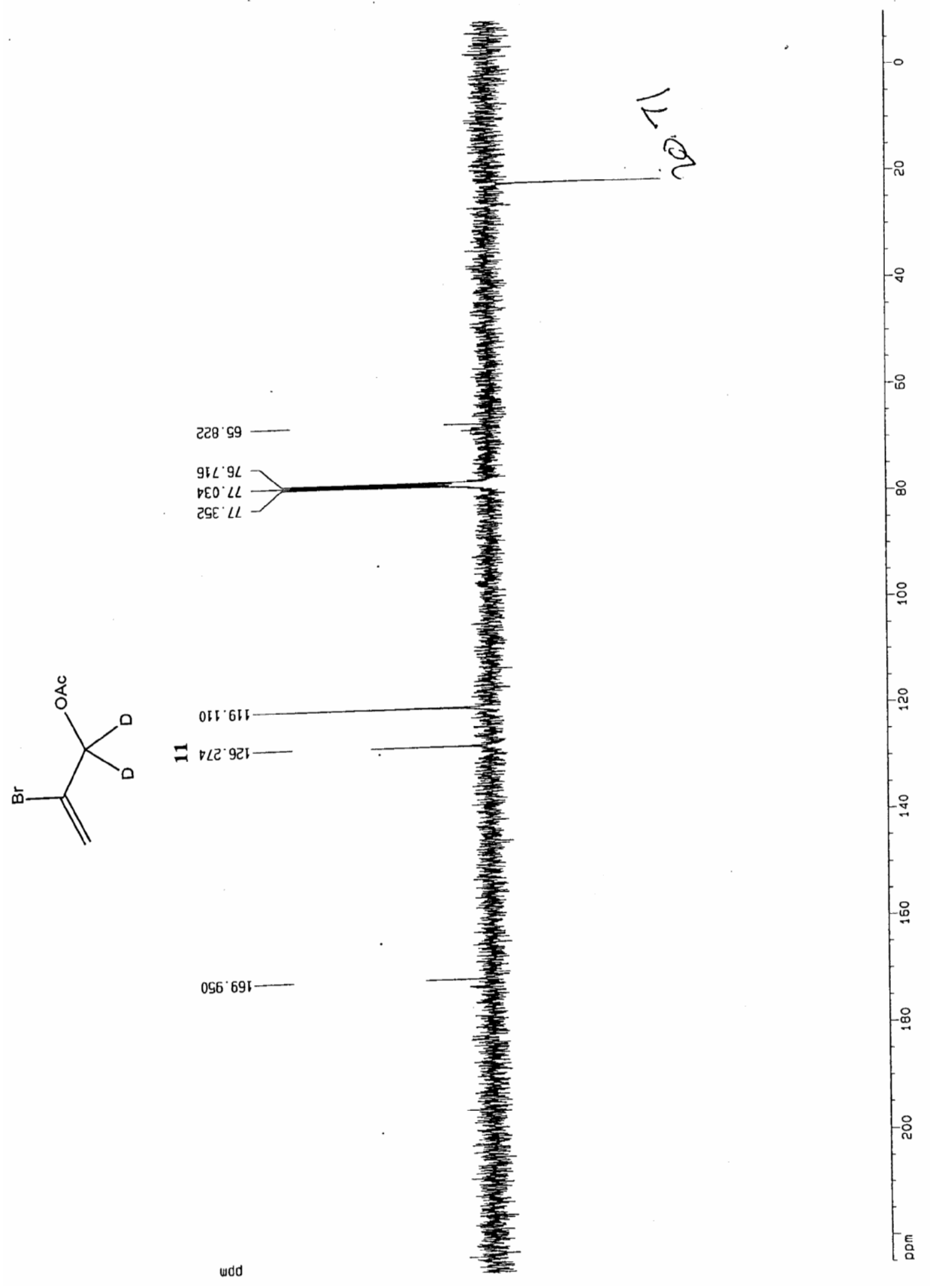




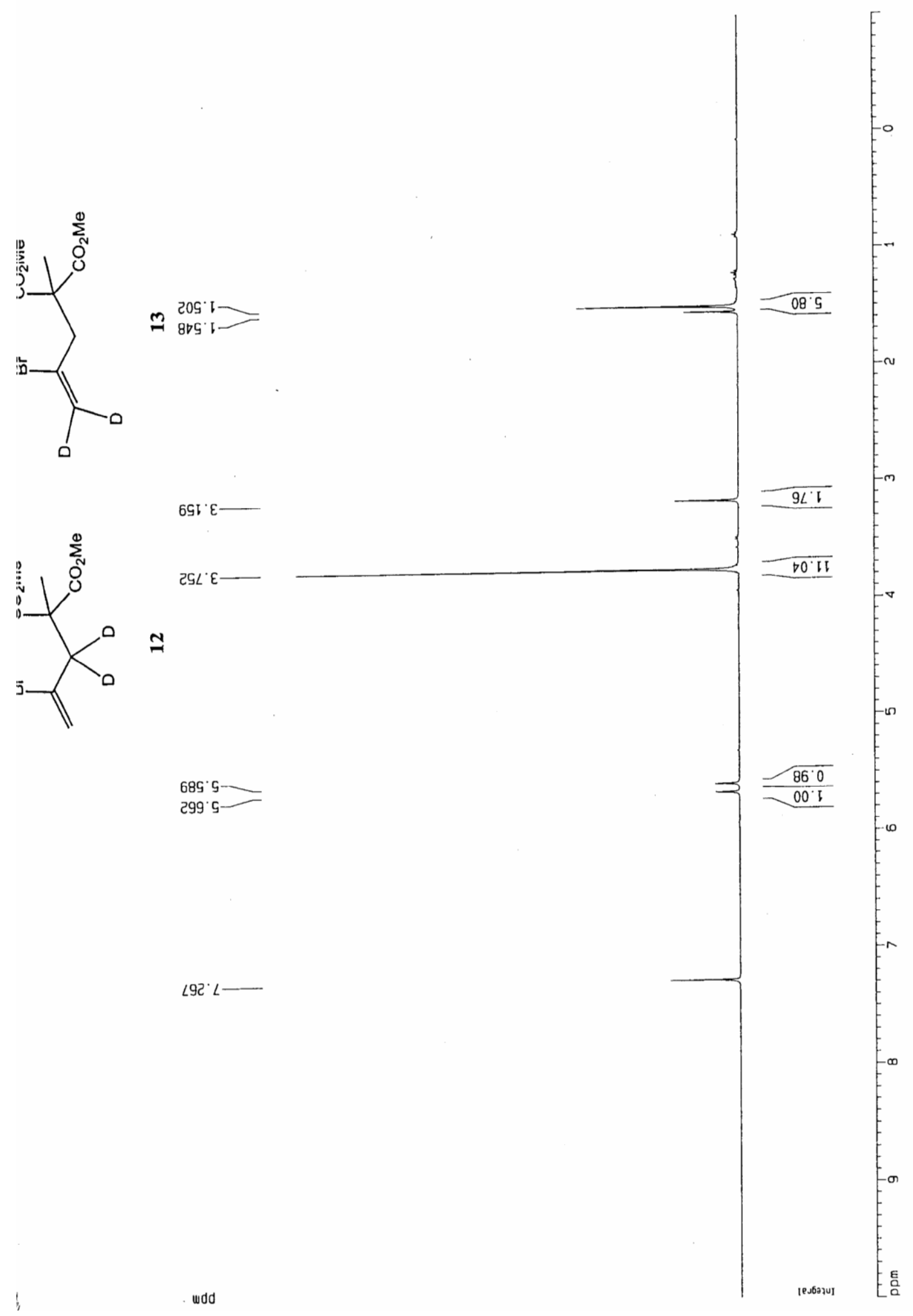




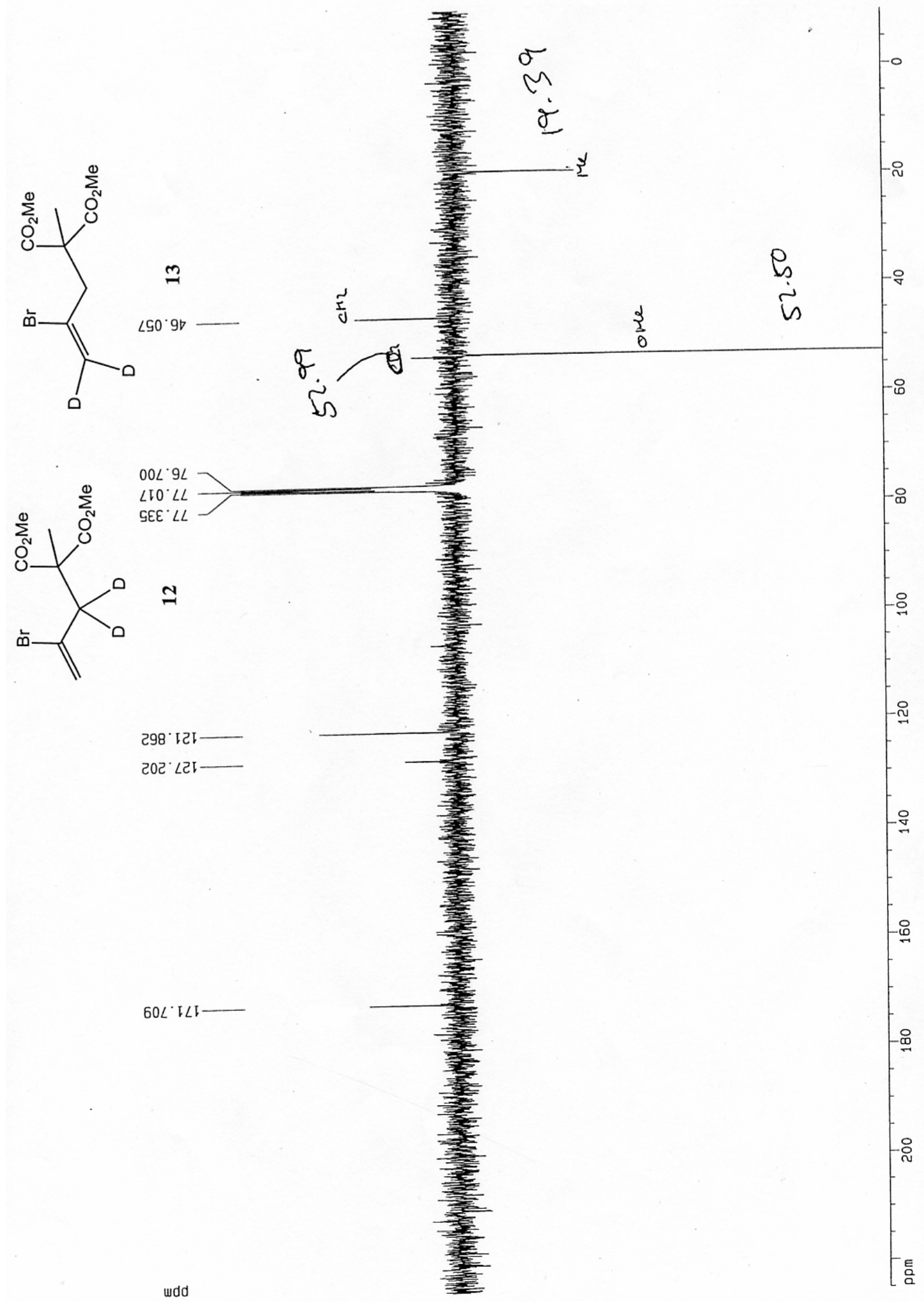




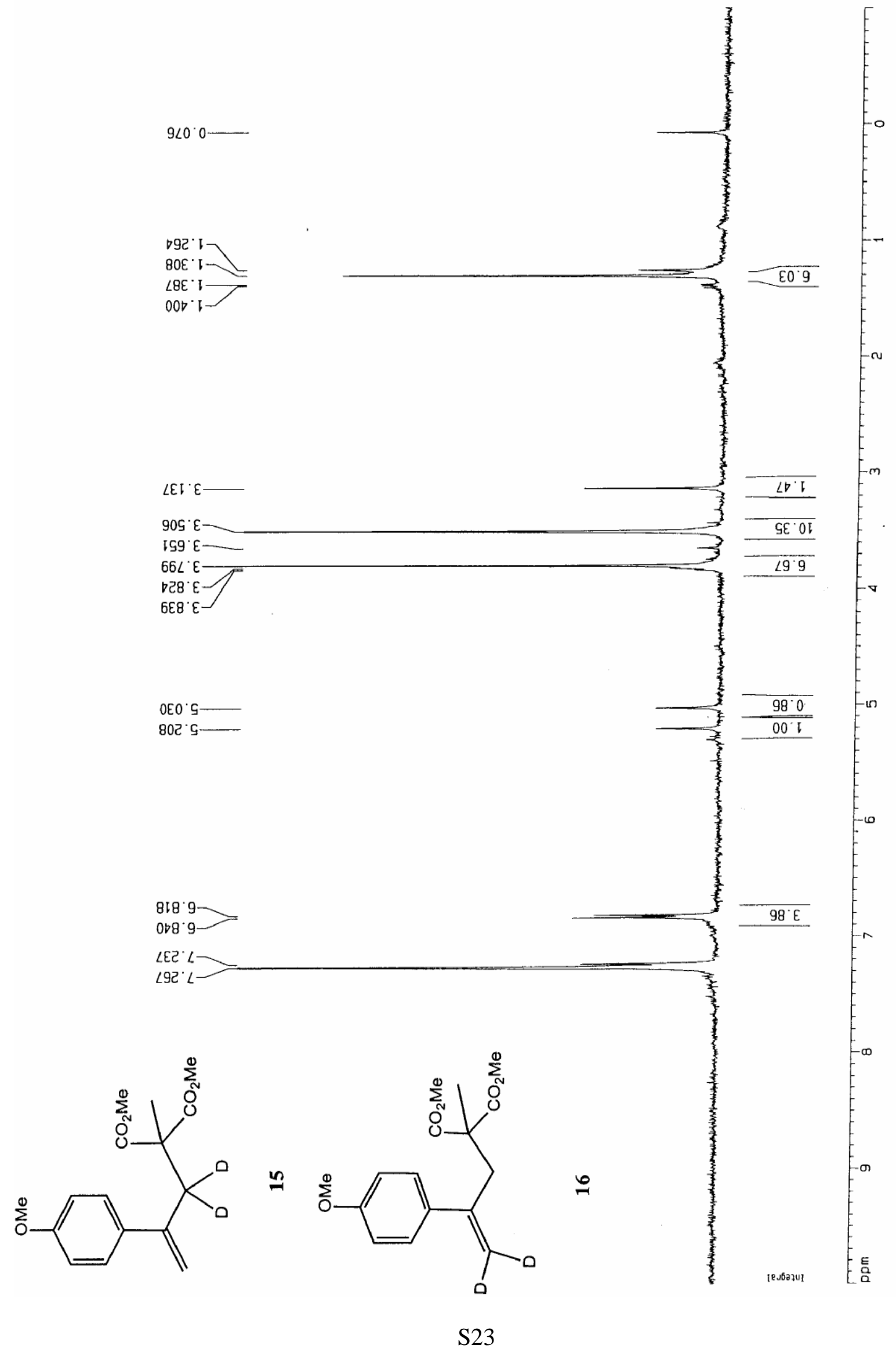



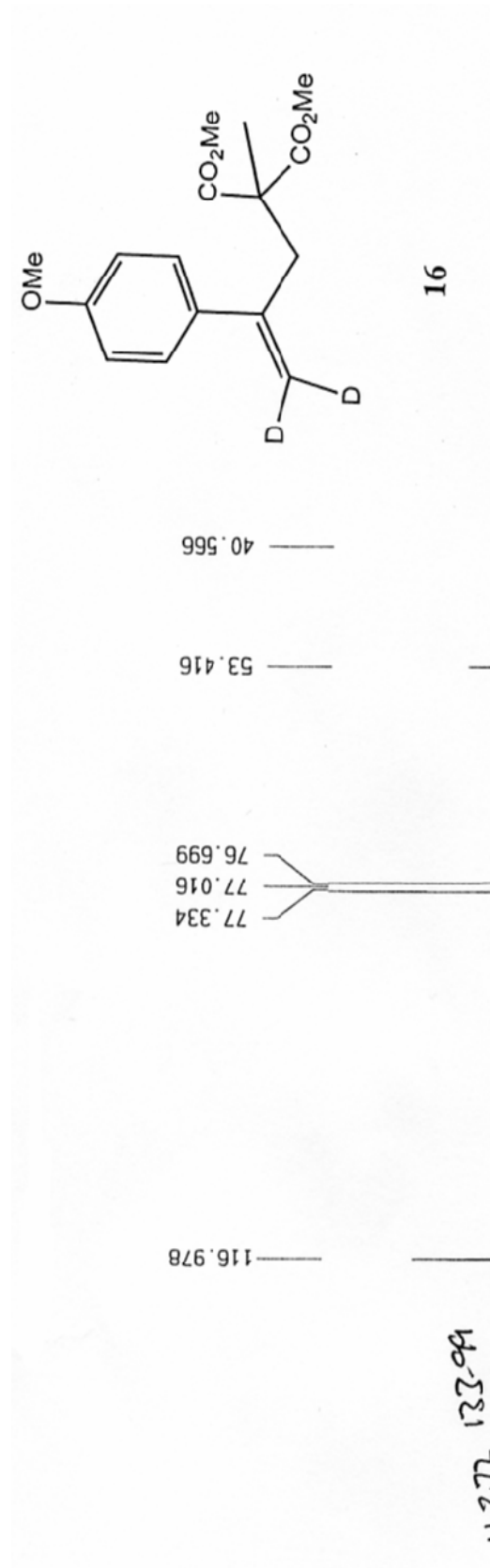

LटI '6G -

Gو2 $2 \angle 1-$

wdd
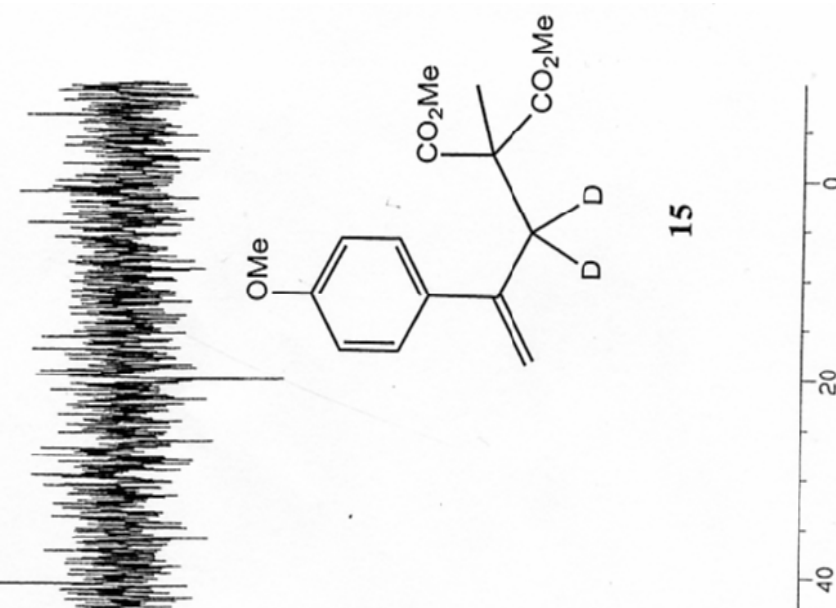

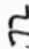

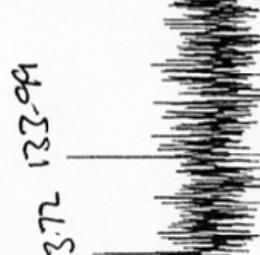

I
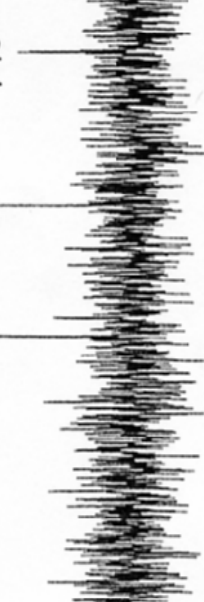


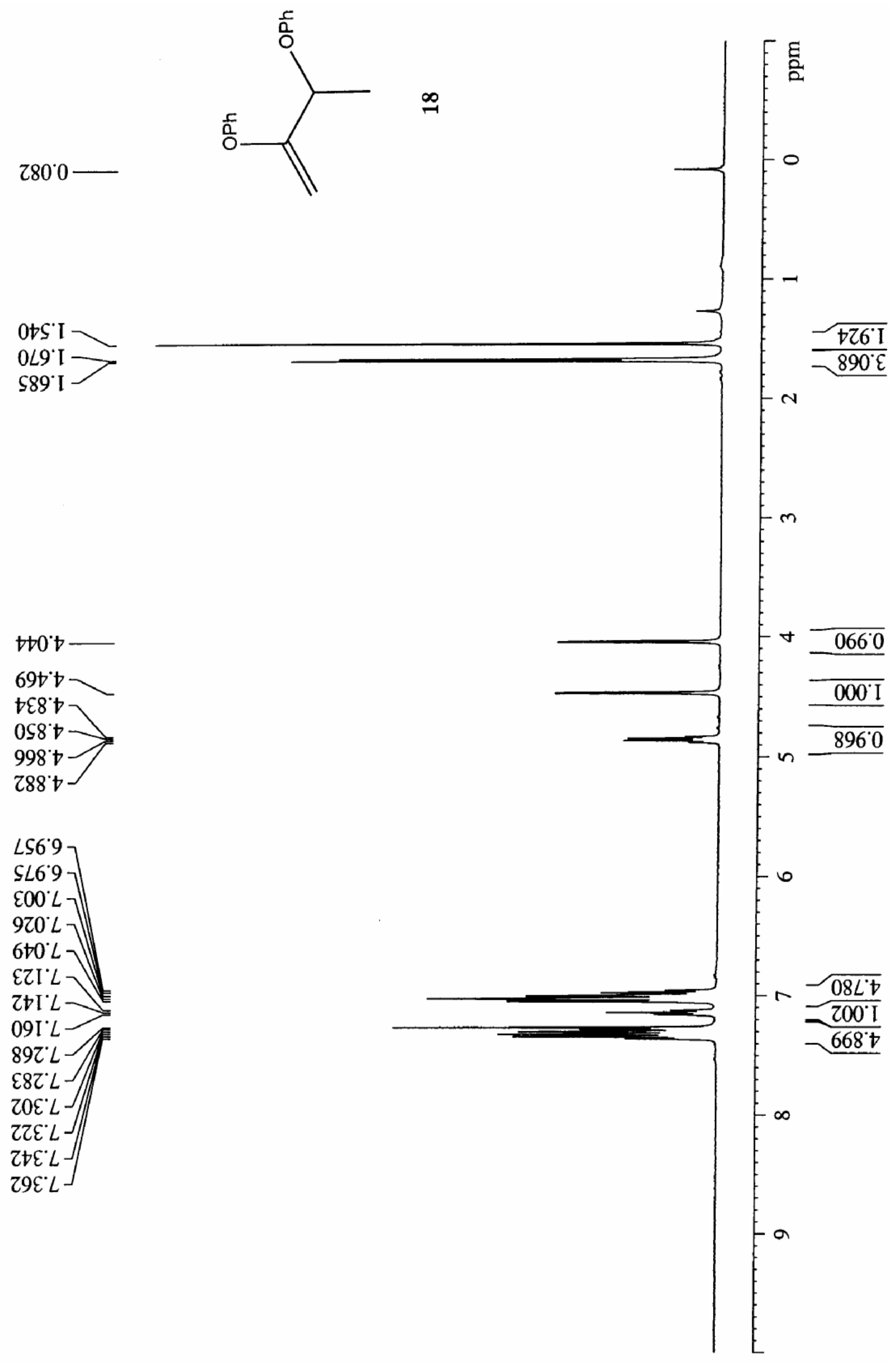




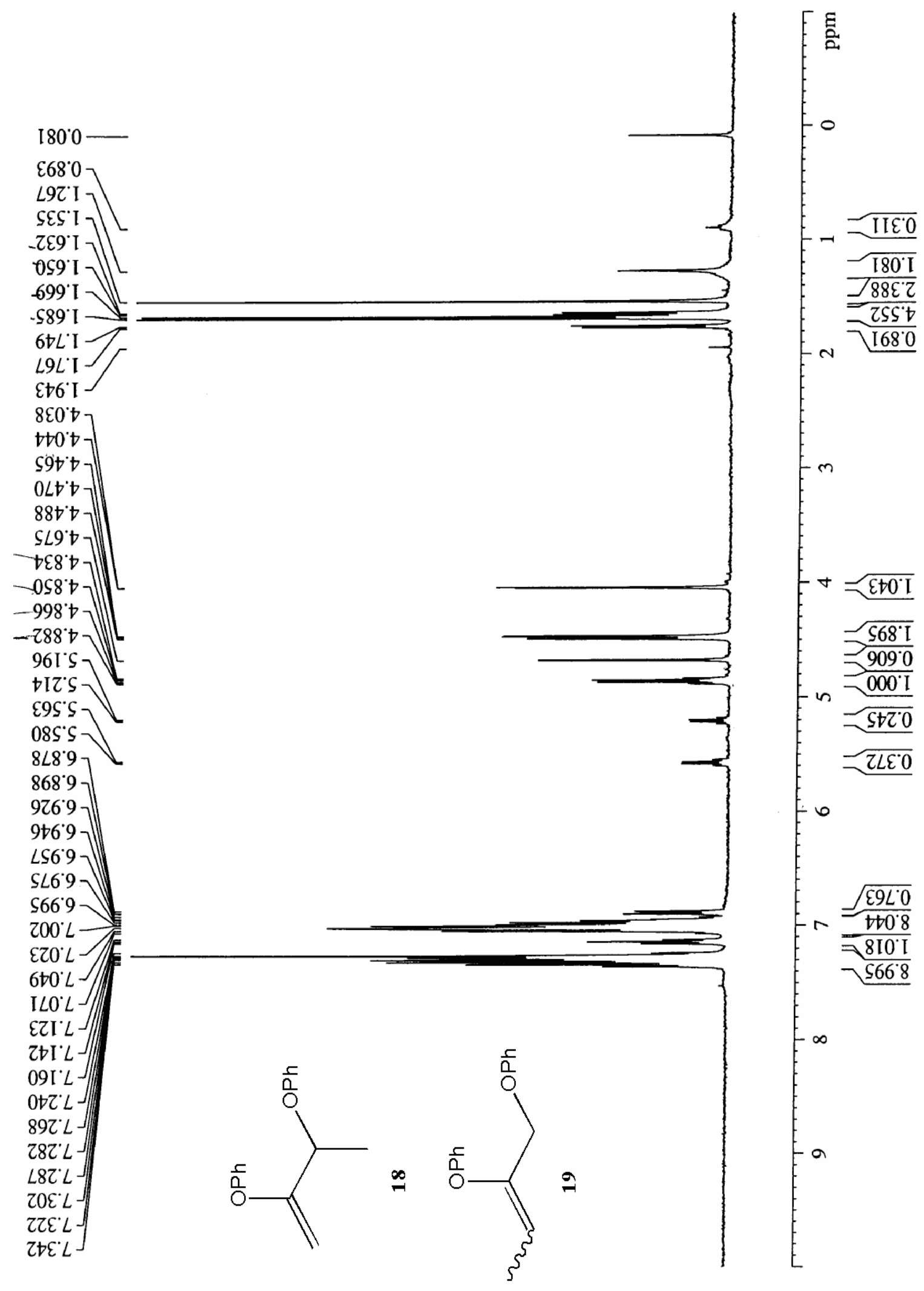




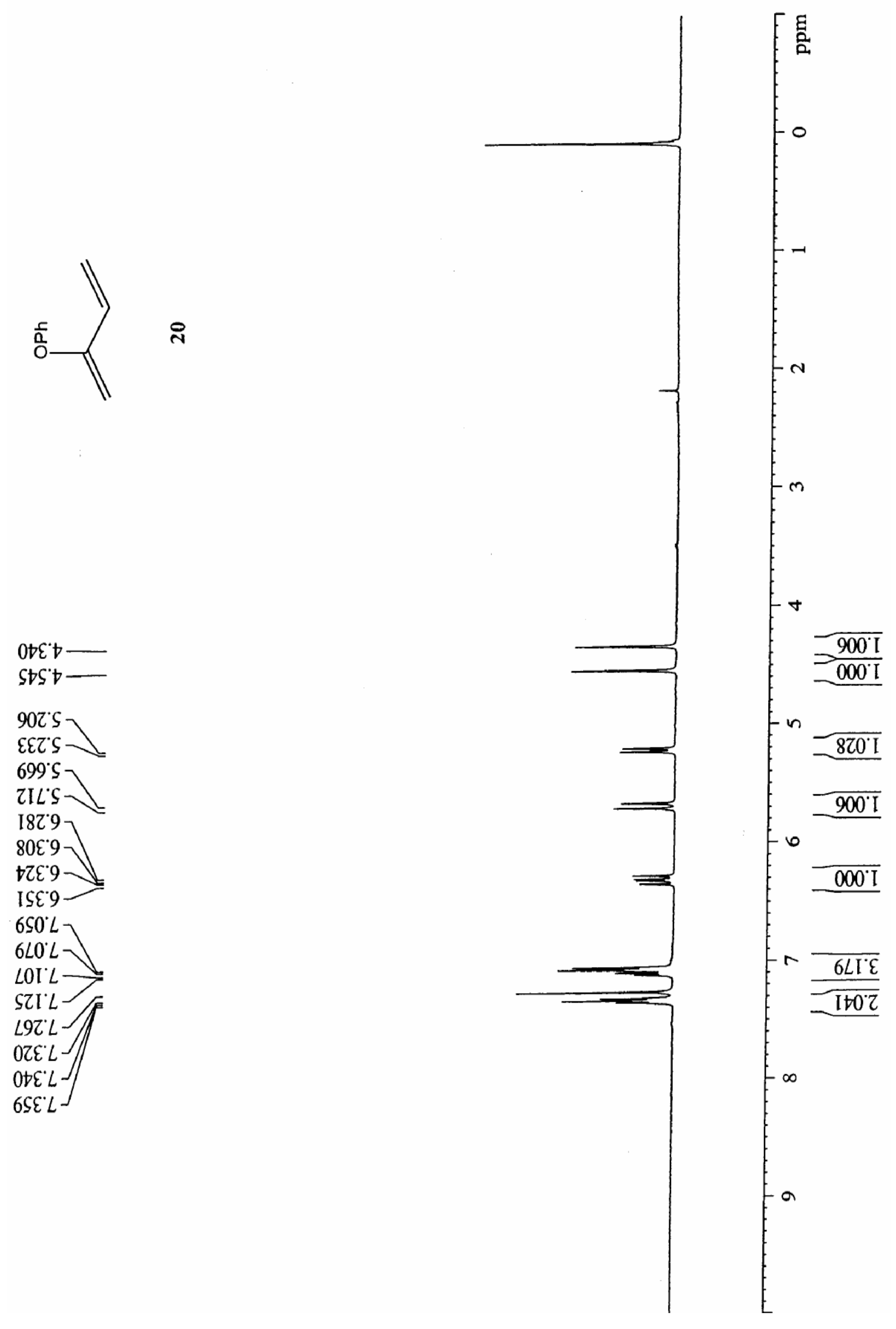




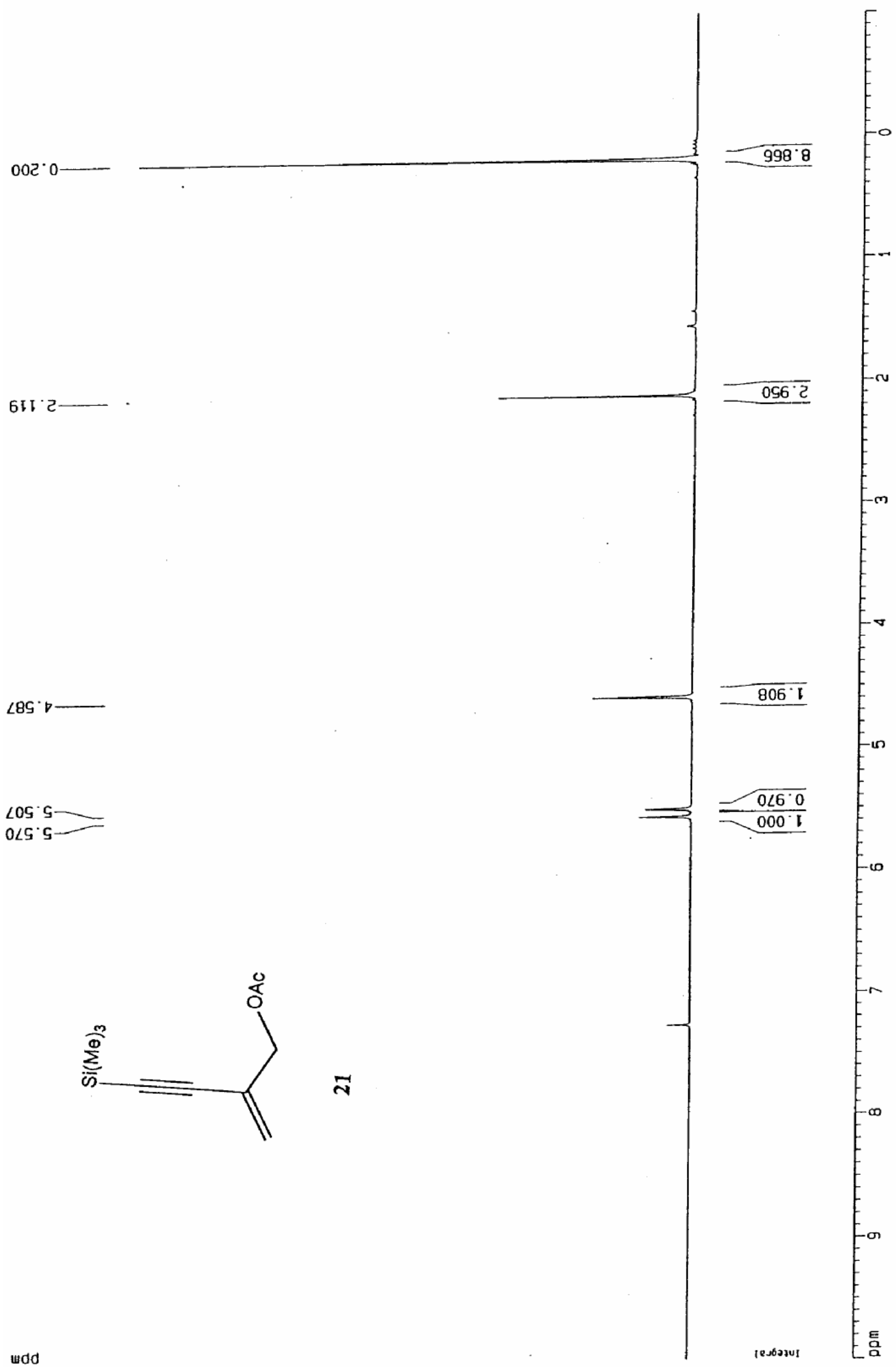




$$
H
$$



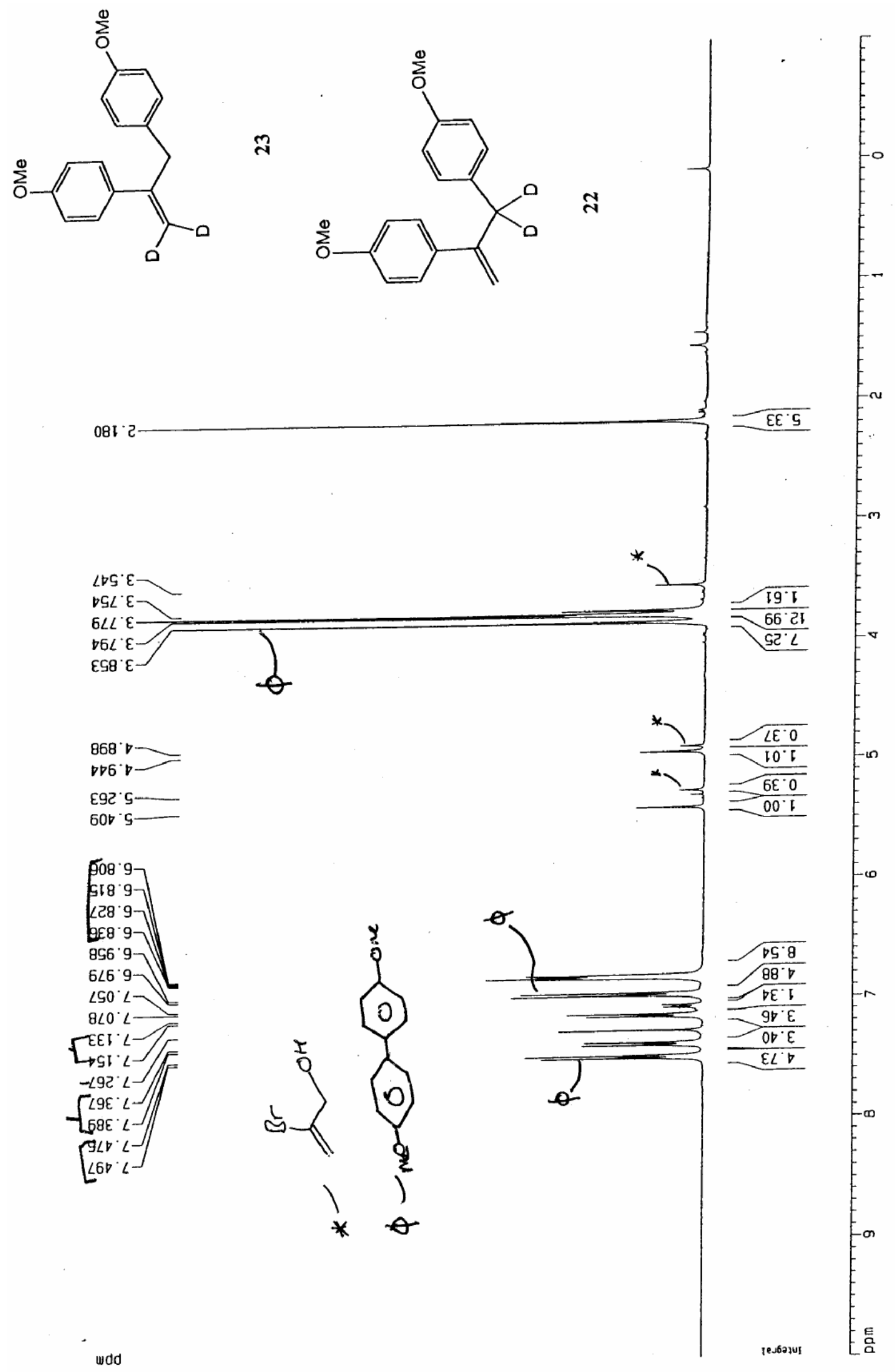


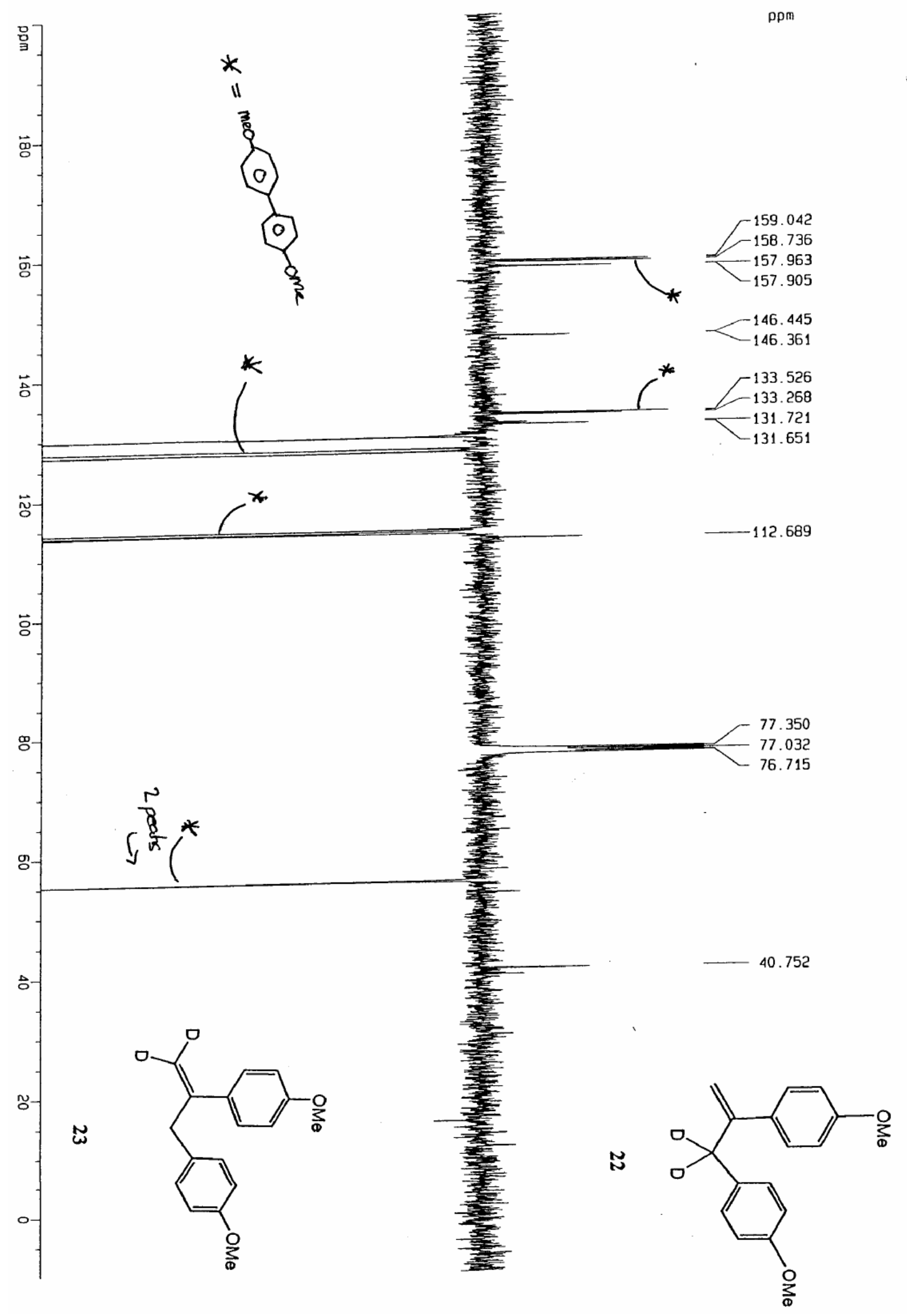



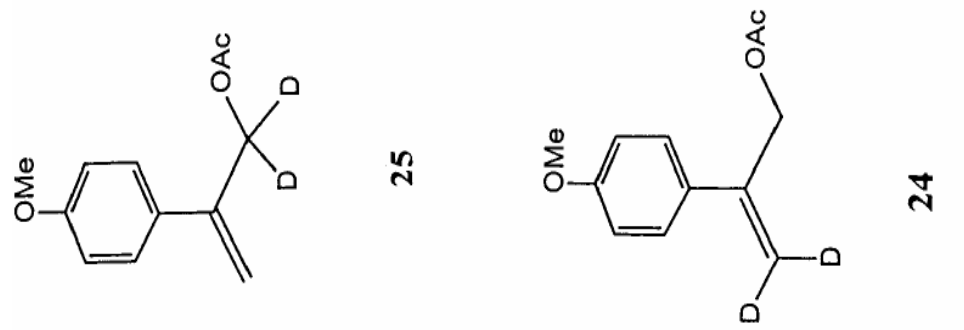

292 . -

$580^{\circ} 2-$
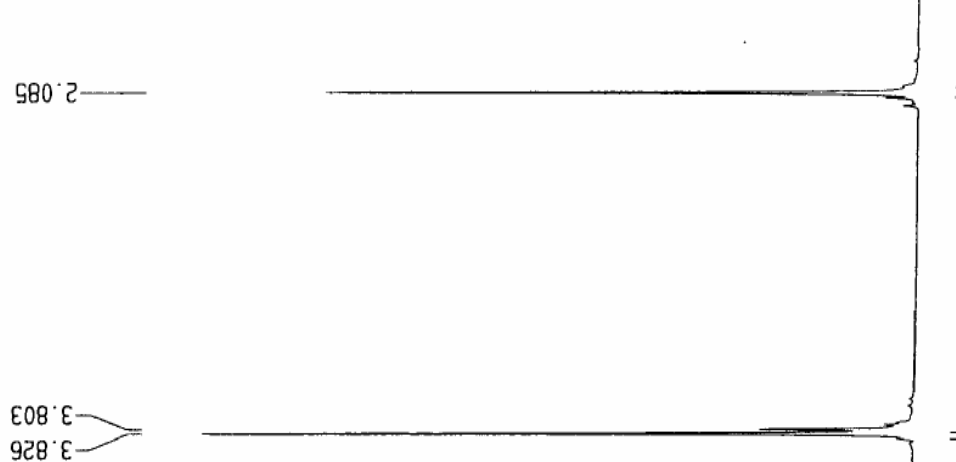

$096^{\prime}$

$282 \cdot \mathrm{G}$

$68 b^{\circ} \mathrm{s}$

$088^{\circ} 9$

106.9

$\angle 92^{\circ} \mathrm{C}$

ILE'L 


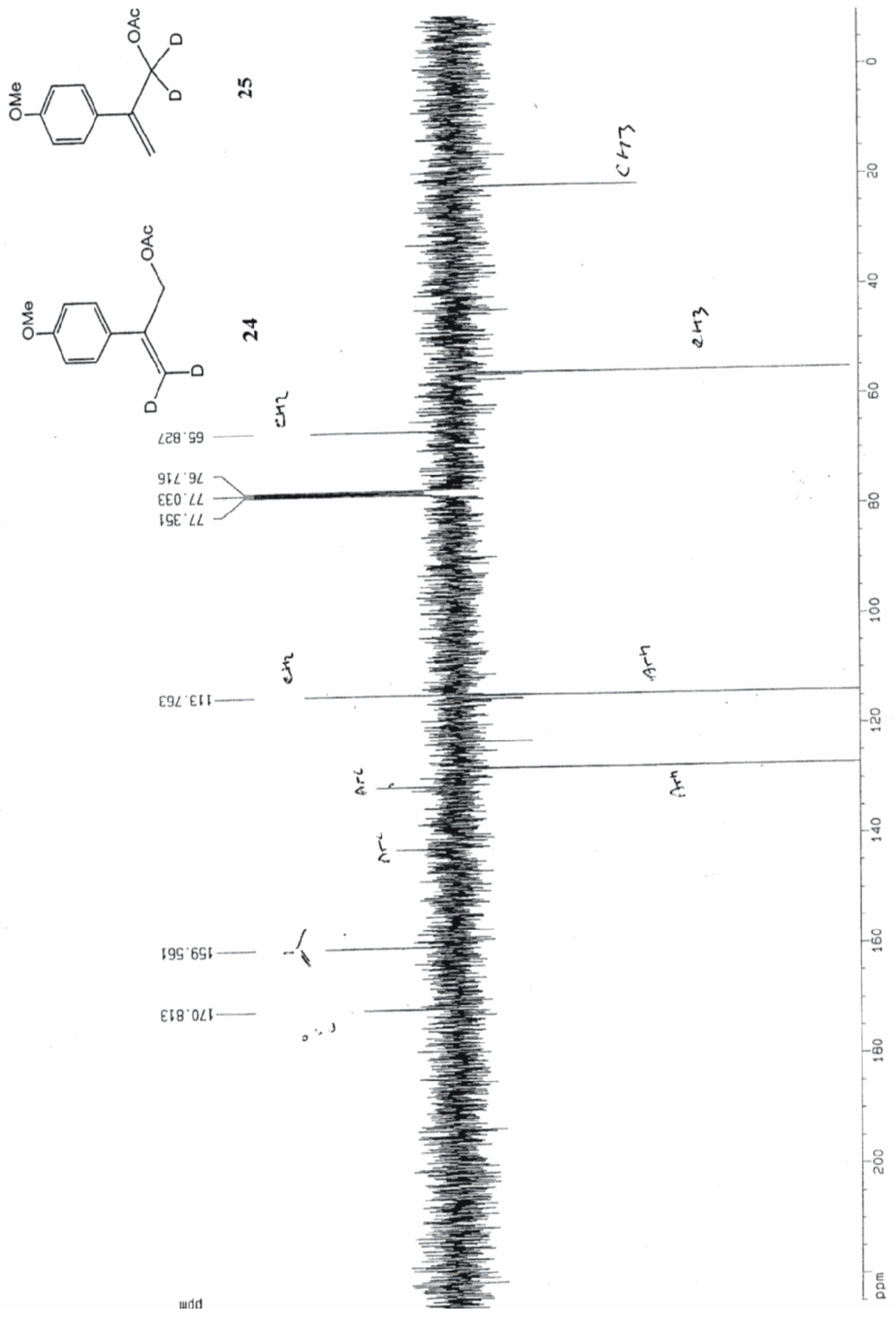


S34 
$60^{\circ} \cdot \mathrm{T}-$

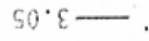

$2 Z \cdot G=$
$Z F \cdot G=$

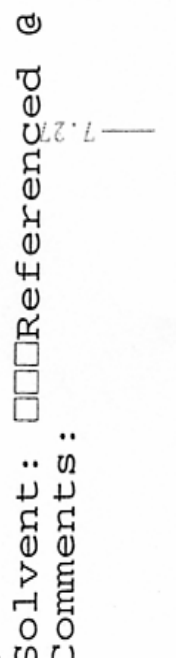

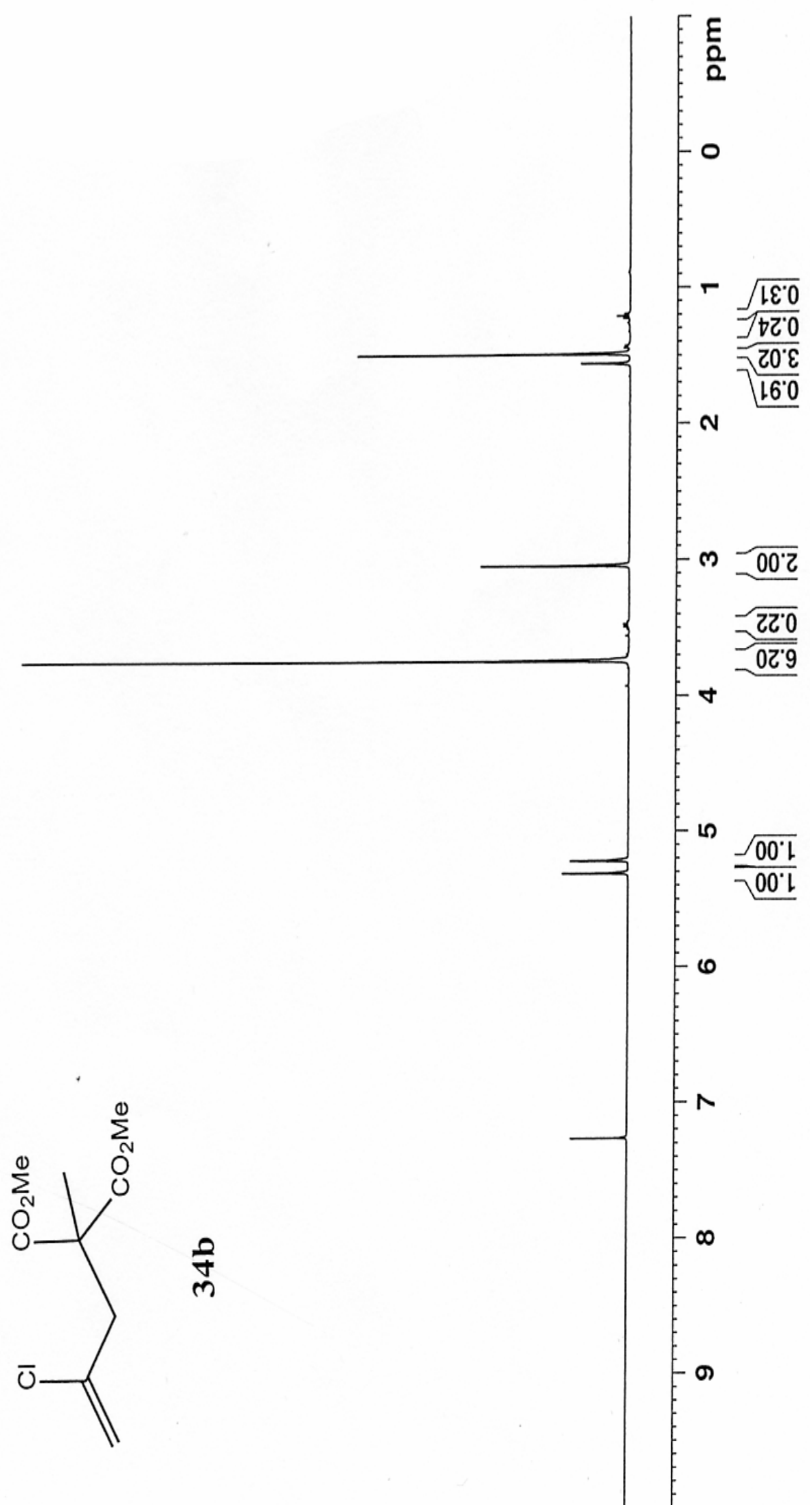



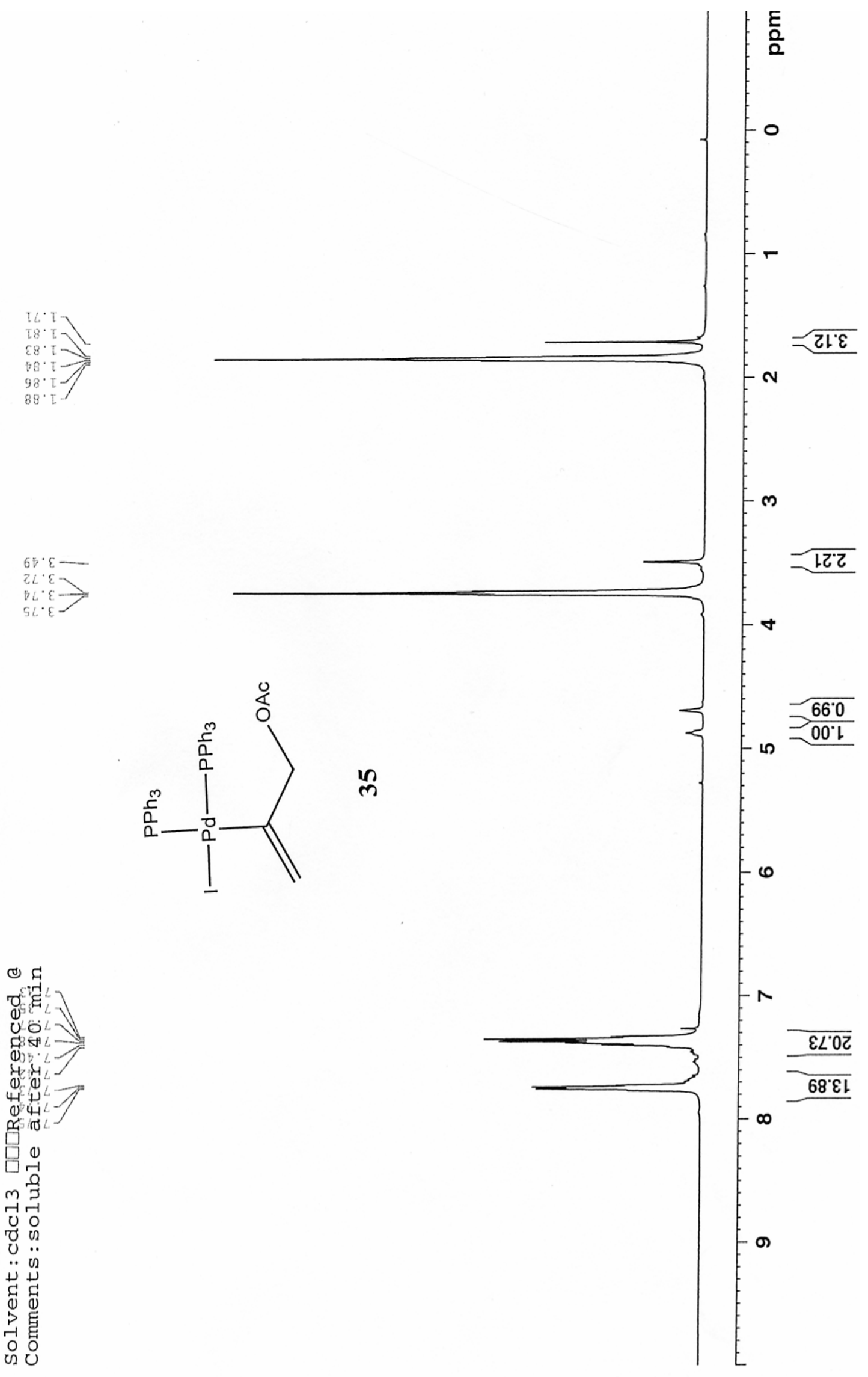


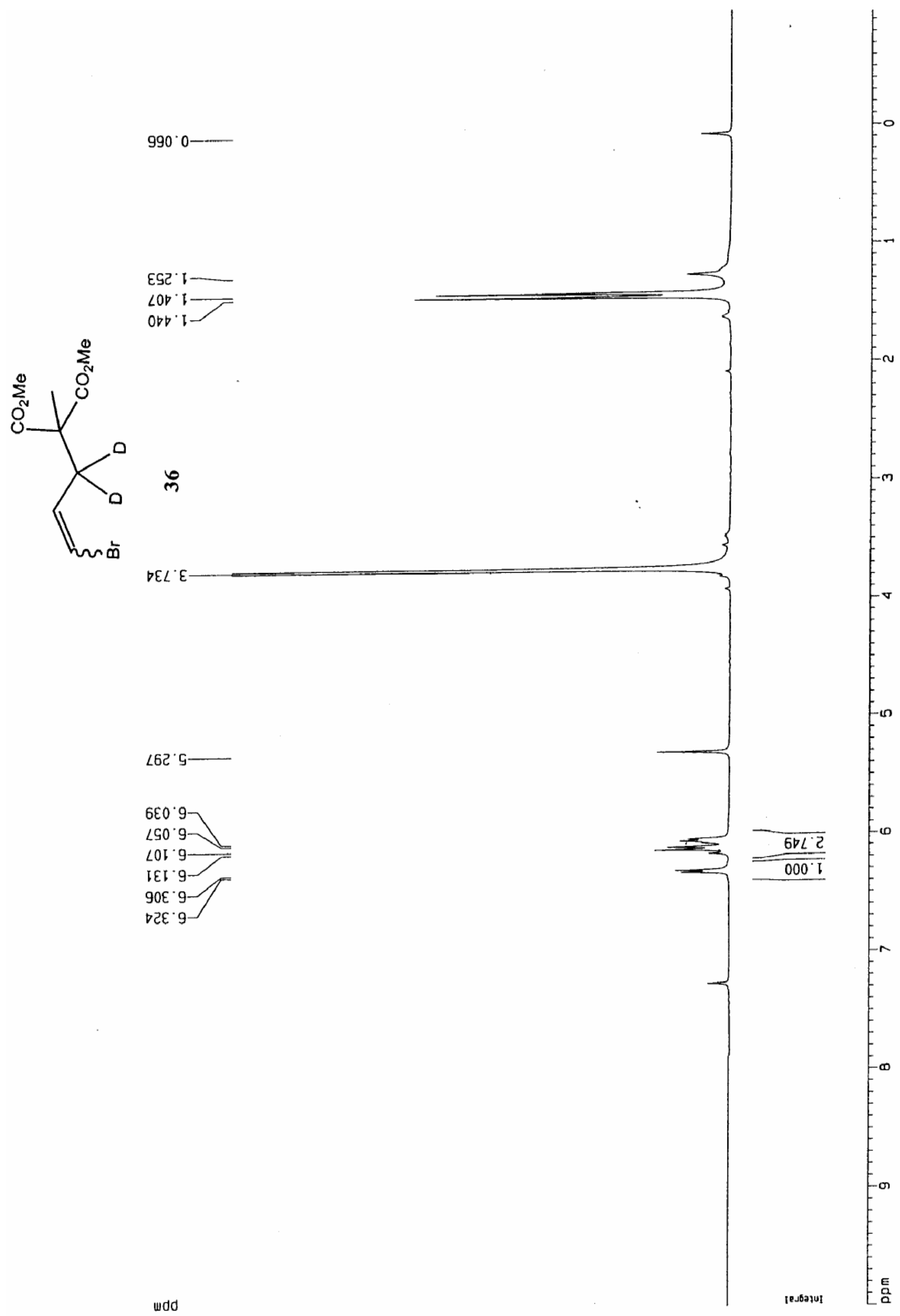




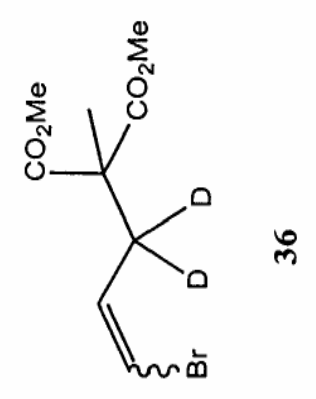

$696 \cdot 25-$

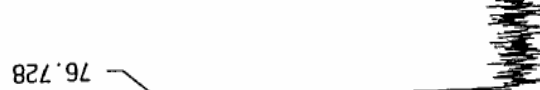

SDO $\angle L$

६९६ 'LL

$\angle 66^{\circ}[\angle I-$

wdd

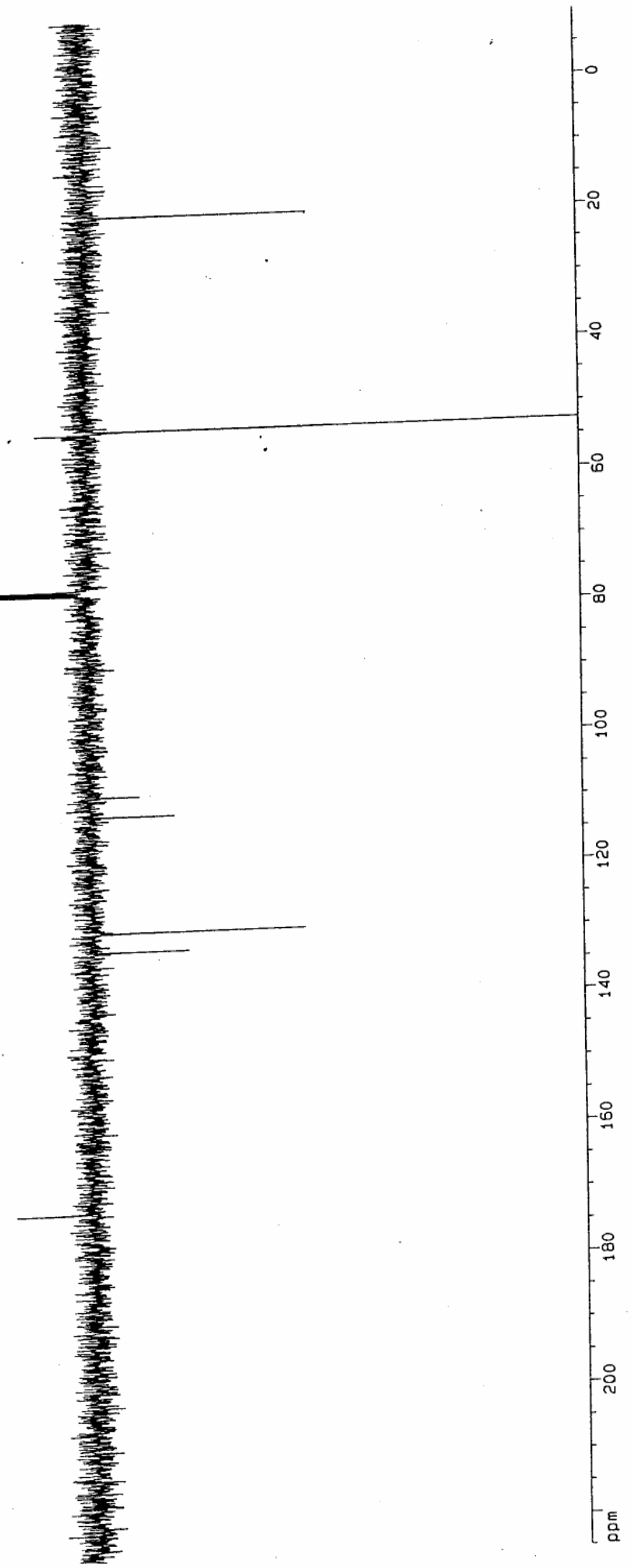




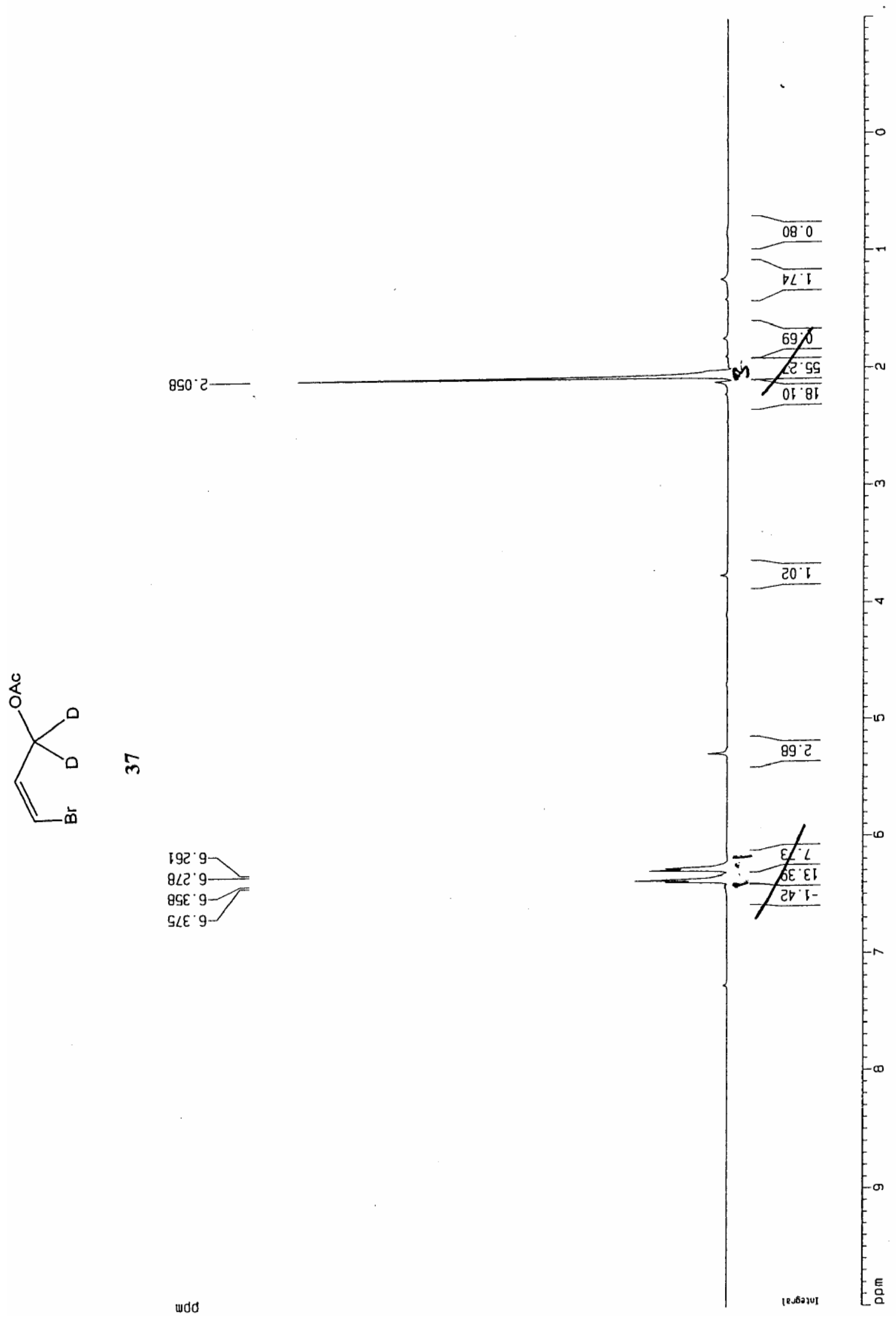




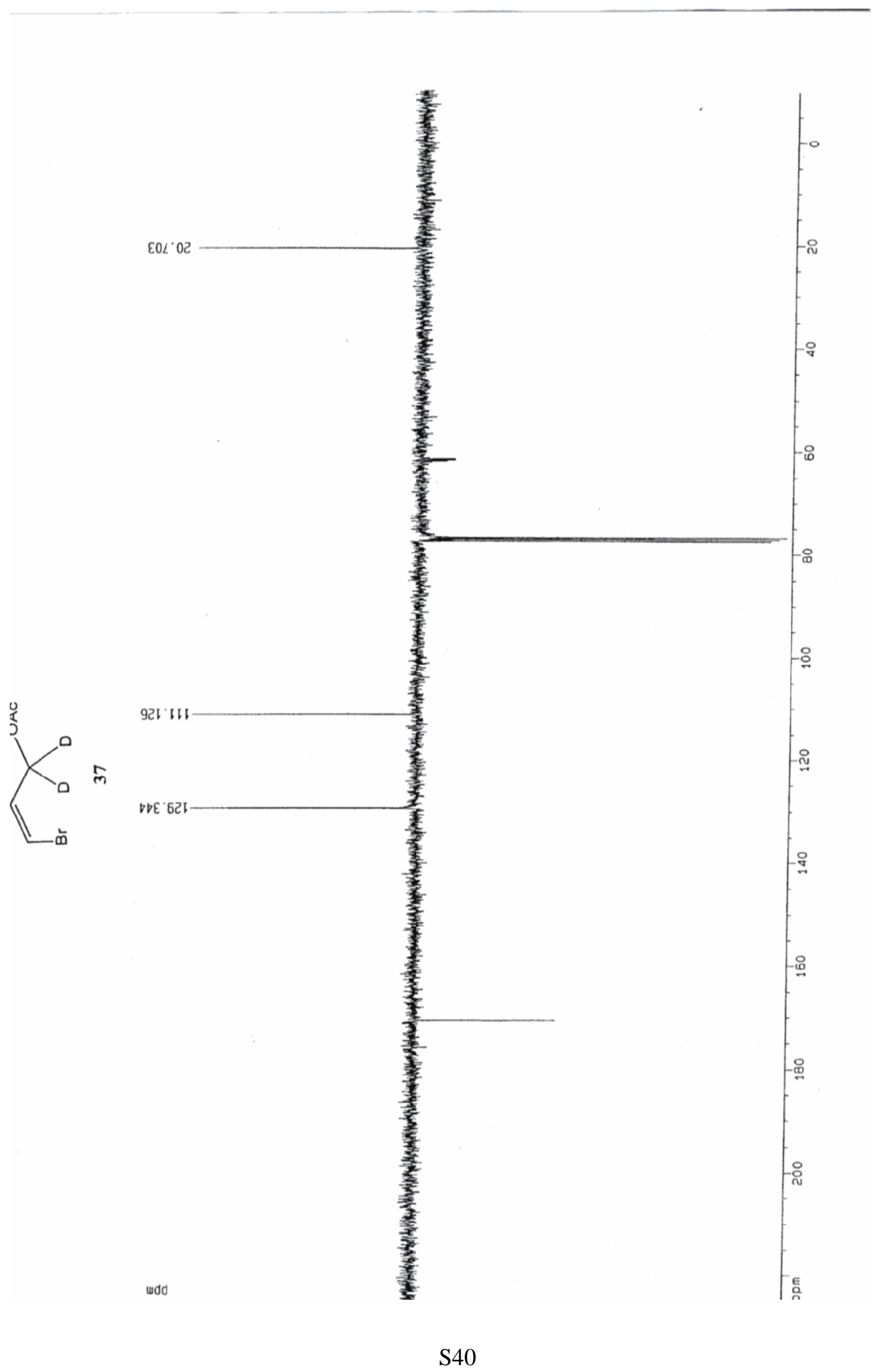




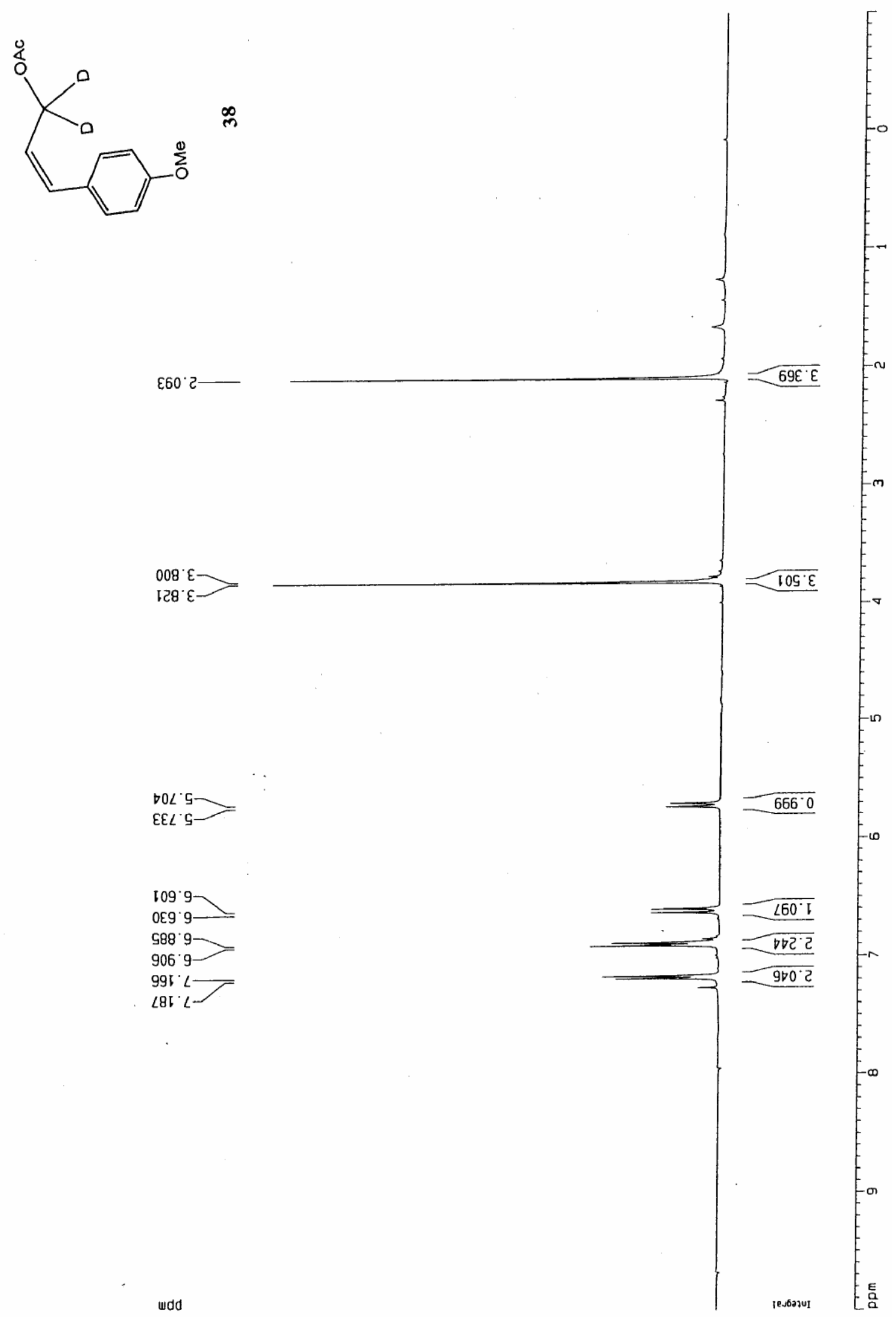




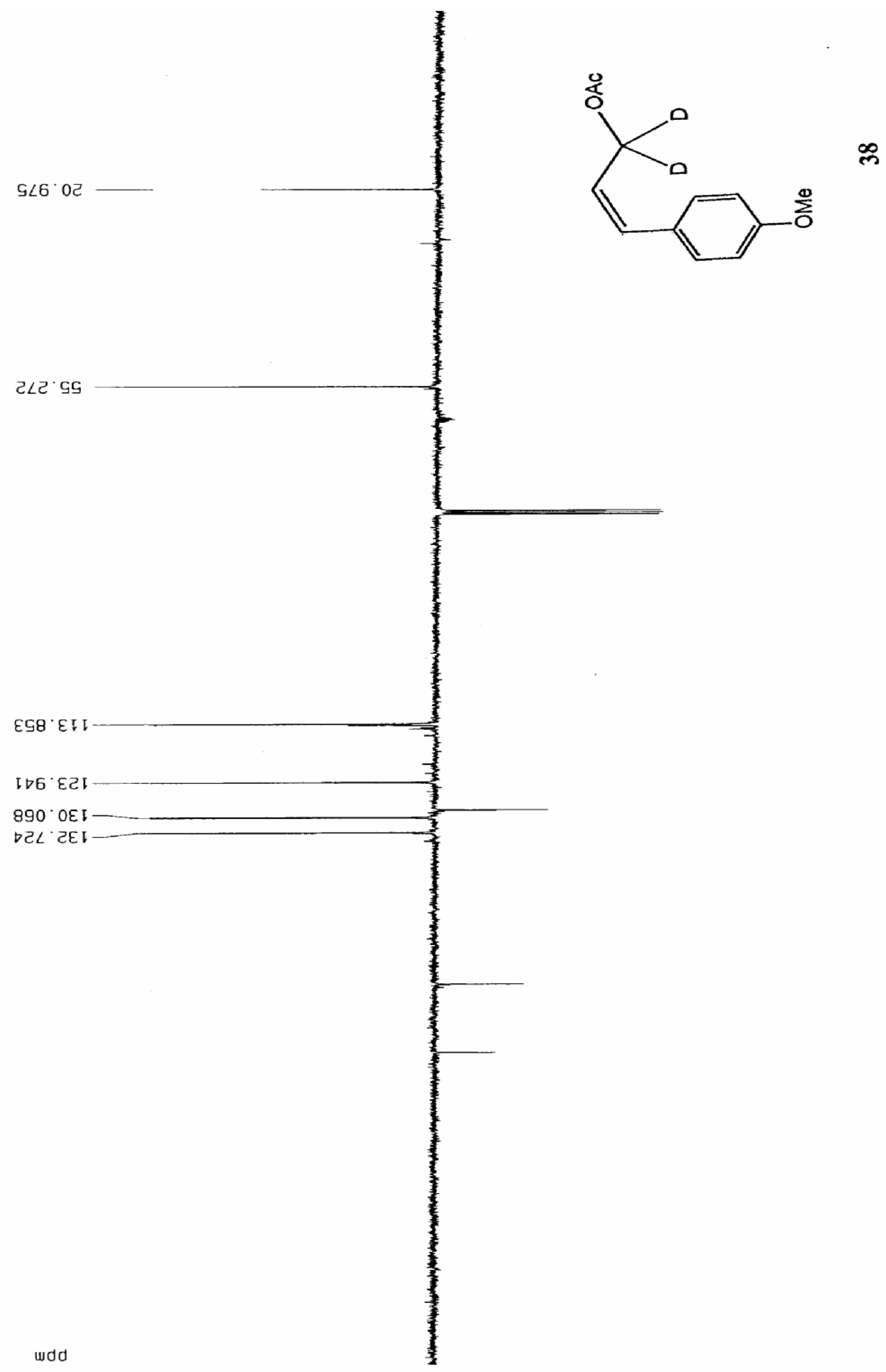

S42 


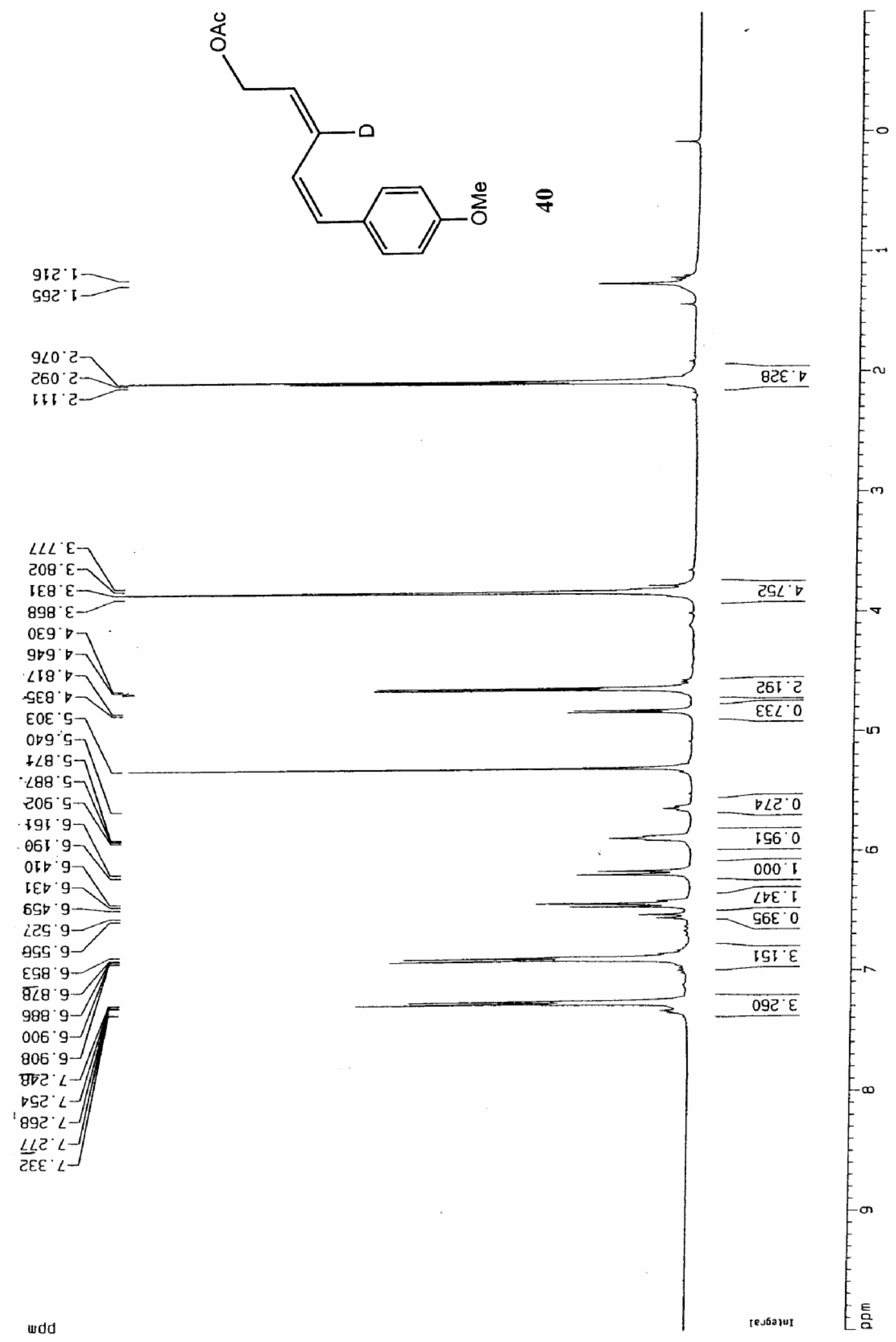




$$
b
$$




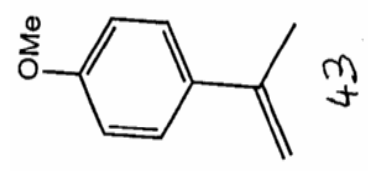

$\angle S D^{\circ} \cdot$

ट૬I '
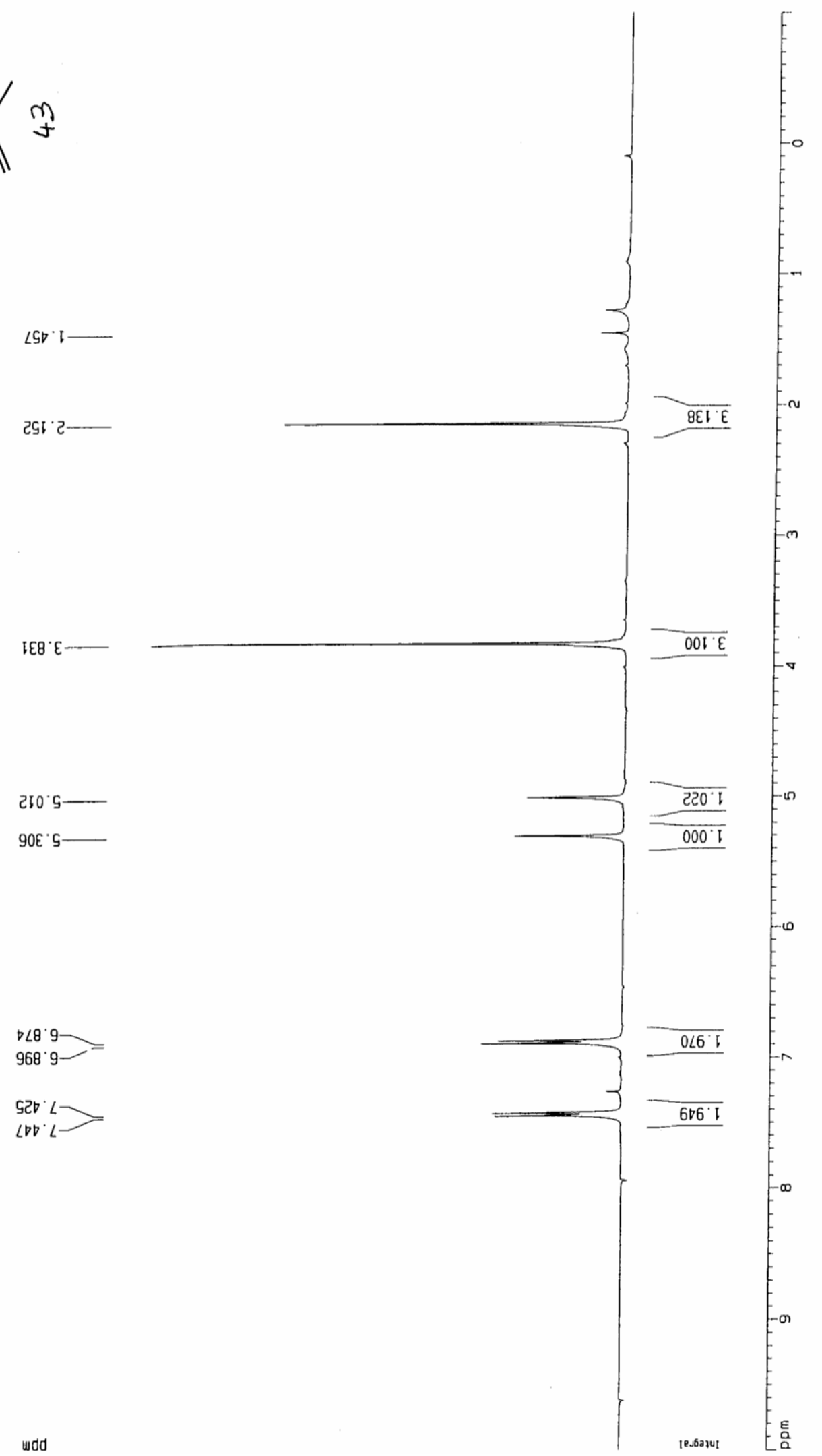

wdd 


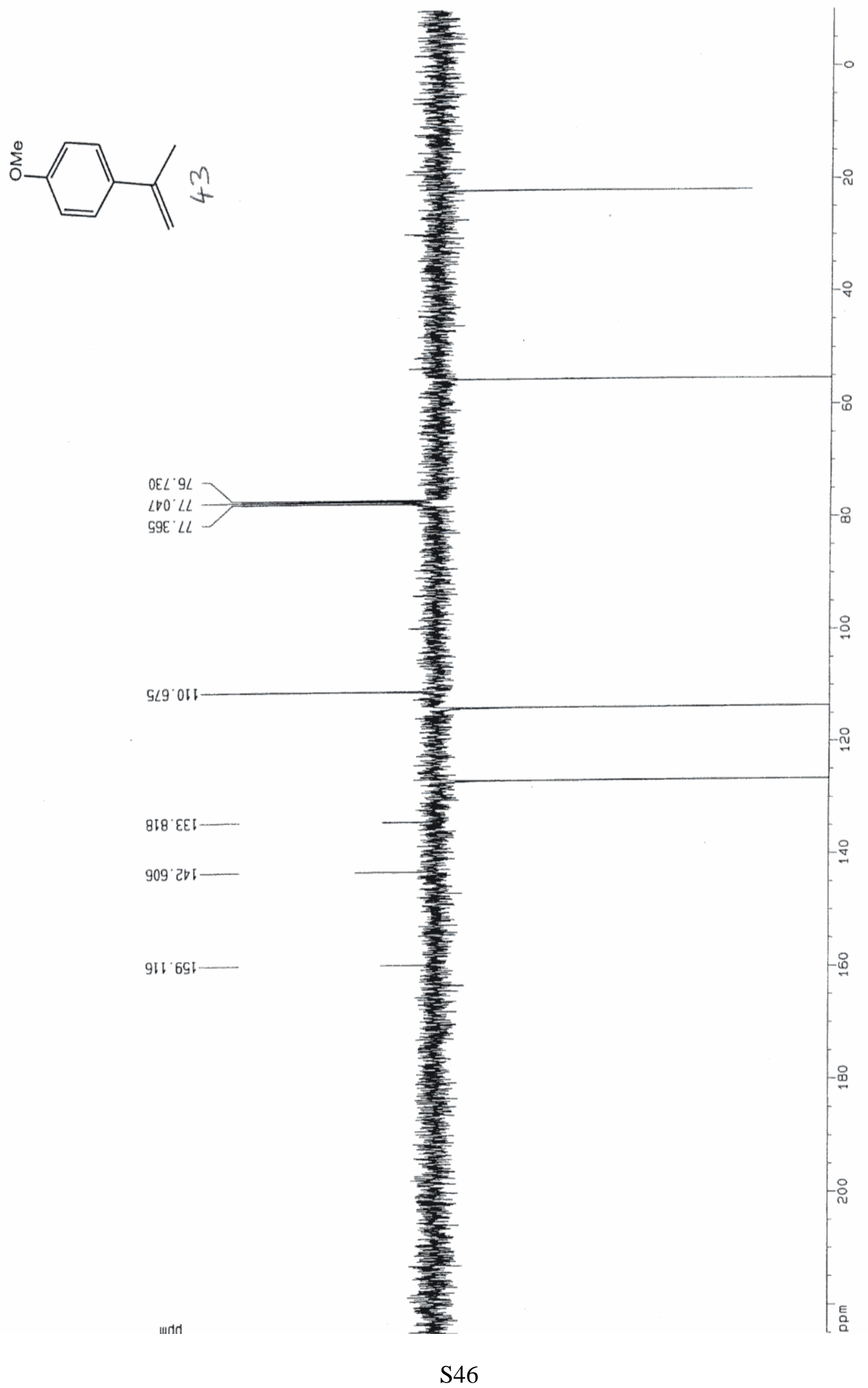




\section{References:}

1 2-Bromo-1,1-dideuterioprop-2-en-1-ol was prepared by reduction of the corresponding methyl ester with $\mathrm{LiAlD}_{4}$ using a procedure adapted from Li, K.; Du, W.; Que, N. L. S.; Liu, H. J. Am. Chem. Soc. 1996, 118, 8763-8764.

2 Taylor, R. E.; Ciavarri, J. P. Org. Lett. 1999, 1, 467-469.

3 3-bromo-2Z-propen-1,1-dideuterio-1-ol was prepared by reduction of the corresponding methyl ester with $\mathrm{LiAlD}_{4}$ using a procedure adapted from Wei, X.; Taylor, R. J. K. J. Org. Chem. 2000, 65, 616-620.

4 Nwokogu, G. C. J. Org. Chem. 1985, 50, 3900-3908.

5 Sonnenberg, J.; Winstein, S. J. Org. Chem. 1962, 27, 748-751.

6 Organ, M.G.; Arvanitis, E. A.; Dixon, C.; Cooper, J. T. J. Am. Chem. Soc. 2002, 124, 1288-1294.

7 Mohri, K.; Mamiya, J.; Kasahara, Y.; Isobe, K.; Tsuda, Y. Chem. Pharm. Bull. 1996, 44, 2218-2222.

8 Organ, M. G.; Arvanitis, E. A.; Hynes, S. J. J. Org. Chem. 2003, 68, 3918-3922.

9 Zecchi, G. J. Org. Chem. 1979, 44, 2796-2798. 